METAZOAN PARASITES OF SALMONIDS AND COREGONIDS FROM COASTAL LABRADOR

TOTAL OF 10 PAGES ONLY MAY BE XEROXED

(Without Author's Permission)

FRANKLIN JOHN HICKS 
15064

Mons 
269356

c. 1

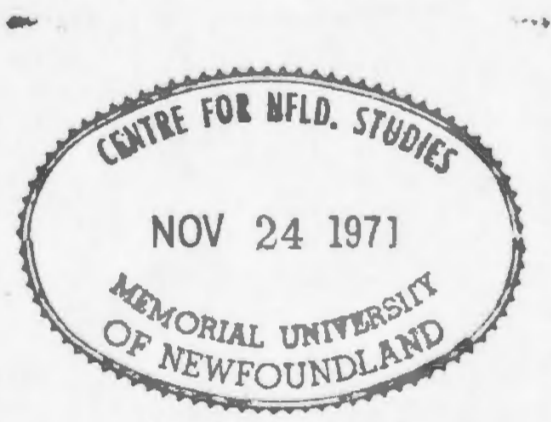





\section{METAZOAN PARASITES OF SALMONIDS AND COREGONIDS FROM COASTAL LABRADOR}

\section{by}

Franklin John Hicks, B. Sc. (Agr.)

A thesis

submitted in partial fulfilment of the requirements for the degree of Master of Science in Biology, Memorial University of Newfoundland.

August, 1971

(c) Franklin John Hicks 1973 
Abstract

323 fish of six species (salmonids and coregonids) from four locations on the eastern coast of Labrador were examined for metazoan parasites, using conventional parasitological techniques.

Twenty-four genera of parasites were recovered ( 3 of Monogenea, 8 of Digenea, 5 of Cestoda, 5 of Nematoda, 1 of Acanthocephala, 2 of parasitic Copepoda). Twenty new host records were noted. Fourteen genera of parasites were noted in Salmo salar I., while Salvelinus fontinalis (Mitchill) contained 21 genera; S. namaycush (Walbaum), 12 genera; S. alpinus (I.), 16 genera; Coregonus clupeaformis (Mitchill), 11 genera; Prosopium cylindraceum (Pallas), 11 genera. It was found that the parasite burden of the various fish species examined was not homogeneous when sample areas and sex of the fish was considered. An increase in the number of parasite species per infected host with age was seen in the case of Salmo salar, Salvelinus fontinalis, S. namaycush, s. alpinus. In Coregonus clupeaformis and Prosopium cylindraceum, no such correlation was seen, this difference being related to the ecology of the fish.

The parasitofauna of the various salmonid species examined was not homogeneous, significant differences being 
noted in the number of certain species infected with specific parasites. Significant differences were also noted in the parasite burden of the Salmonidae when compared with the Coregonidae.

Food items recovered from the fish autopsied were noted. 


\section{Acknowledgements}

Much credit belongs to the many people who have helped me, directly or indirectly, in the preparation of this thesis.

I thank Memorial University of Newfoundland for the Fellowship that I was awarded and Dr. M. Laird of the Biology Department for the facilities he provided.

Dr. W. Threlfall, my faculty advisor, who provided encouragement, guidance and helpful criticism throughout the thesis programme is to be particularly commended.

Mr. G. Hanek, who accompanied me to Labrador, assisted greatly in the field work.

Thanks are also extended to Dr. D. H. Steele and Prof. J. Phipps, for assistance in identifying invertebrate food items, and particularly the latter professor for his helpful criticism of the thesis.

Dr. A. May, Fisheries Research Board of Canada, and his staff and Mr. R. Peet, of the Resource Development Branch, Department of Fisheries provided assistance in aging the fish. 
Without the help of the typing of Mrs. S. H. Lee, the finished copy woula not have been possible.

Finally, many thanks are extended to my. wife, Patricia, for her help and encouragement throughout the preparation of this thesis. 


\section{Table of Contents}

Page

Abstract

Acknowledgements

List of Tables

vi

List of Figures

viii

Introduction

Materials and Methods

Results and Discussion

Salmo salar

10

Salvelinus fontinalis

23

Salvelinus namaycush

Salvelinus alpinus

41

Coregonus clupeaformis

48

Prosopium cylindraceum

51

General Discussion

60

Summary

74

References

81 
List of Tables

Page

Table 1. Details of origin and number of salmonid and coregonid species examined and percentage infected with helminths and parasitic copepods.

Table 2. Details of infection of Salmo salar, Salvelinus fontinalis, salvelinus namaycush, Salvelinus alpinus, Coregonus clupeaformis and Prosopium cylindraceum, with metazoan parasites, from coastal Labrador.

Table 3. Checklist of parasitofauna, with location of infection, of salmo salar, salvelinus fontinalis, salvelinus alpinus, Salvelinus namaycush, coregonus clupeaformis and Prosopium cylindraceum from coastal Labrador.

Table 4. Details of infection of Salmo salar, with metazoan parasites, from st. Mary's River, Eagle River, Nain and Grand Lake.

Table 5. Relationship between the number of parasite species and age of salmo salar.

Table 6. Details of infection of Salvelinus fontinalis, with metazoan parasites, from Mt. Mary's River, Eagle River, Nain and Grand Lake.

Table 7. Measurements (microns) of Gyrodactylus sp. recovered from Salvelinus fontinalis and comparison with Gyrodactylus elegans (var.B) Mueller, $193 \overline{6}$.

Table 8. Measurements (microns, unless indicated otherwise) of Proteocephalus tumidocollus and comparison with type specimens of Wagner, 1953.

Table 9. A comparison of morphological characteristics of the two forms of Proteocephalus sp. recovered from Salvelinus fontinalis from Labrador. 
List of Tables (contd.)

Table 10. Relationship between the number of parasite species and age of Salvelinus fontinalis.

Table 11. Details of infection of Salvelinus namaycush, with metazoan parasites, from Nain and Grand Lake.

Table 12. Relationship between the number of parasite species and age of Salvelinus namaycush.

Table 13. Details of infection fo Salvelinus alpinus, with metazoan parasites, from Nain and Grand Lake.

Table 14. Relationship between the number of parasite species and age of salvelinus alpinus.

Table 15. Details of infection of Coregonus clupeaformis, with metazoan eparasites, from Grand Lake.

Table 16. Details of infection of Prosopium cylindraceum, with metazoan parasites, from Grand Lake.

Table 17. Measurements (microns) of Tetraonchus variabilis recovered from Labrador, and a comparison with the original description of Mizelle and Webb, 1953.

Table 18. Food items found in fish from coastal Labrador. 
List of Figures

Page

Figure 1. Sampling areas: (1) St. Mary's River,

(2) Eagle River, (3) Nain and

(4) Grand Lake.

Figure 2. Anchors and marginal hook of

Gyrodactylus sp. from Salvelinus

fontinalis from coastal Labrador.

Figure 3. Scoleces of (a) Proteocephalus

tumidocollus, (b) Proteocephalus sp.

TType II) and (c) Proteocephalus sp.

(Type I) recovered from Salvelinus

fontinalis from coastal Labrador.

Figure 4. Haptoral armament and copulatory complex of Tetraonchus variabilis Mizelle and Webb, 1953, from coastal Labrador.

Figure 5. Ergasilus luciopercarum Henderson, 1926, from Prosopium cylindraceum from coastal Labrador. 


\section{Introduction}

Labrador, in the words of sir Wilfred Grenfell (1913), is "unexplored but invigorating" with an "almost stygian darkness that hangs still over it and its resources." Since Labrador was first sighted by the Vikings, this shroud has slowly been lifted by missionaries, mining and timber companies and the indomitable Newfoundland fisherman.

Little work of a scientific nature other than geological surveys, has been done in Labrador to date, and the helminth fauna of salmonids and coregonids has been particularly neglected. Andrews and Lear (1956), Davis (1953), Frost (1940) and Munroe (1949) made brief mention of some of the larger and more obvious species of helminths in these groups of fishes. The only works concerned primarily with the parasites of fishes have been those of Hanek and Threlfall (1970a,b,c,a) Pippy (MS., 1969) and Threlfall and Hanek (1970 a, b).

Due to the economic importance of salmonids and coregonids, a great number of parasitological studies have been performed on these fish, particularly in the Holarctic. The literature is extensive, much of it having been collected in the following works: Bykhovsky et al. (1962), Choquette (1948), Cooper (1915), Dawes (1947), Dogiel and Petrushevski (1935), 
Dollfus (1942), Heller (1949), Hoffman (1967), Heitz (1917), Markevich (1951) and Richardson (1936).

Yamaguti compiled existing records of parasite taxonomy in his Systema Helminthum $(1953,1958,1961,1963)$. The present study is an attempt to expand our knowledge of the metazoan parasite fauna of salmonids and coregonids of coastal lakes and rivers of Labrador. In addition, this parasitological survey provided an unique opportunity of comparing the helminth fauna of island and mainland populations composed of similar species, i.e. insular Newfoundland (Pippy M.Sc., 1965; Sandeman and Pippy, 1967) and the Labrador watershed.

Backus (1957), presented a concise ichthylogical report dealing with the biology and distribution of fishes in Labrador.

The recreational value of the freshwater fishery. has been generally overlooked when compared with the marine fishery, which in the Western North Atlantic is economically important. It is only with increased leisure and a public demand for more recreational facilities, that authorities have become aware of the sportsmens' revenues and the need to examine and preserve this fishery. In particular, it is unwise not to consider the freshwater phase of anadromous species common to both fisheries. 
Salvelinus fontinalis (Mitchill) and s. alpinus (Linnaeus) commonly make seaward migrations, but do not range far from their native stream (Leim and Scott, 1966). In contrast, Salmo salar Linnaeus, upon entering the sea, may travel hundreds of miles, returning to freshwater only to spawn (Leim and Scott, 1966). Once on the high seas, they are subject to a very intense fishing pressure, such that the participating nations have had to sign a treaty limiting fishing activities in the North Atlantic (I.C.N.A.F., 1970). Studies therefore, on the helminthofauna of the Atlantic salmon has increasing relevance in the separation of the various stocks into their respective breeding ranges, whether it be North America or Europe. Margolis (1963), utilized parasites as biological tags in a study of the Sockeye salmon, Oncorhynchus nerka (Walbaum) on the Pacific West coast. In Newfoundland, Pippy (MS., 1969) made initial application of this technique to the Atlantic salmon. The rivers of Labrador, although poorly surveyed, undoubtedly provide a substantial stock to this fishery.

Frequently in studies of this nature, essential information about the host, the parasite and their respective habitats are lacking, making it impossible to study parasite host interactions. Dogiel in a series of papers (1933, 1935, and 1958), initiated an ecologically orientated study of parasitism in Russia. Among others Baer (1952), Noble (1960). 
and Theodorides (1954) have since taken this approach in their work.

In Russia, Pavlovski (1934) recognized the dual environment which exerts an influence on the growth and survival of the parasite. There is the immediate or micro-environment, consisting of the host. In the microenvironment, a consideration of the total parasite burden in an organism and the subsequent interaction embodies Noble's (1960) concept of parasite-mix. The external or macro-environment, occupied by the host itself, imposes different conditions on ectoparasites as well as the freeliving infective stages of endoparasitic forms. It is only with morphological, physiological and biological data concerning the host, that we can begin to understand factors affecting the parasite.

According to Dogiel (1962), "Parasitology should concern itself not only with the parasite and the host, but also with those relationships and adaptations, which arise as a result of one animal taking its abode in or on another". This study attempts to maintain a similar ecological approach . 
Materials and Methods

Three hundred and twenty-three fish from four locations along the eastern coast of Labrador were examined for metazoan parasites during the period July to september, 1969 (Table I, Figure 1). Major lakes and rivers, if readily accessible, were sampled in a given area, to give more depth to the study and to obtain the maximum number of species available. Transportation along the coast of Labrador was by Canadian National Railway's coastal steamer service.

The fish were caught with a 30 foot hand seine, gill net or by angling. A few (10) were obtained from commercial fishermen. As many specimens as possible were maintained alive for fresh examination. The remaining fish were preserved in formalin (10\%) and shipped to Memorial University for examination later. Conventional parasitological techniques were employed in the investigation of all fish.

Monogenetic trematodes were fixed in a mixture of glycerol and ammonium picrate (Malmberg, 1956) and examined by phase contrast microscopy. Drawings were made with the aid of a camera lucida. Digenetic trematodes and cestodes were relaxed in urethane $(1 \%)$ and fixed and stored in ethanol (70\%). Later, they were stained using semichon's 
aceto-carmine and mounted, mainly in Canada balsam. Permount or Histoclad was tried on a number of occasions with varying degrees of success. A modified celestin blue staining technique (Riser, 1949) for cestodes was also used. Nematodes were fixed in glacial acetic acid (Berland, 1961a) and stored in glycerine-alcohol solution (schell, 1962). Rubin's fluid (Rubin, 1951) was used for mounting small nematodes, only the larger nematodes requiring prior clearing in lactophenol. Acanthocephala were relaxed in urethane (18) or left standing in water, then fixed and stored in ethanol $(70 \%)$. Outstanding results were obtained using a modified version of Lynch's precipitated borax carmine method of staining as outlined by Bullock (1969). Parasitic copepods were fixed and stored in ethanol (70\%) and later cleared and mounted in Rubin's fluid.

Morphological and biological data, including scales for aging purposes, were collected from the fish as described by Lagler: (1956). Length and weight information was compared with similar studies (Cable, 1956; Dubois et al., 1968; Lagler, 1947; Mraz, 1964; Nordeng, 1961; Peet, 1971) in order to obtain a representative aging of the Labrador sample. Reading of scales was facilitated by a Bausch and Lomb micro-projector. 
All the statistical tests employed in this work, using raw data, were $(2 \times 2)$ or $(2 \times c)$ contingency classifications (Simpson, Roe, Lewontin, 1960). Attempts were made to determine whether there was any relationship between the sex of a particular fish species and its parasite burden, or whether there was any significant difference in the parasitofauna of a species of fish from various localities along the Labrador coast, that is, was the parasite burden homogeneous? Tests were also performed to determine whether or not all the salmonid species examined had a similar burden, the same tests being applied to the coregonid species. Finally, the parasite burden of salmonid and coregonid species were compared.

Measurements are in microns unless otherwise indicated. Terminology and taxonomy of fishes is in accordance with Leim and Scott (1966) and American Fisheries Society, Special Publication No. 2 (1960). Common names of fishes were derived from extensive ichthyological reports of Backus (1957), Leim and Scott (1960), Mackay (1963), McPhail and Lindsey (1970). 
Table 1. Details of origin and number of salmonid and coregonid (in parentheses) infected with helminths and parasitic c

\begin{tabular}{|c|c|c|c|c|}
\hline $\begin{array}{c}\text { Fish } \\
\text { Species }\end{array}$ & $\begin{array}{l}\text { St. Mary's } \\
\text { River*a }\end{array}$ & $\begin{array}{l}\text { Eagle } \\
\text { River* }\end{array}$ & $\begin{array}{l}\text { Trouser } \\
\text { Lake* }\end{array}$ & $\begin{array}{l}\text { Nain } \\
\text { Nain } \\
\text { Harbour** }\end{array}$ \\
\hline salmo salar & & & & \\
\hline grilse $e^{b}$ & $12(100$ & $22(100)$ & - & - \\
\hline smolt & $1(100)$ & $2(100) * \star *$ & - & - \\
\hline parr & $9(100)$ & $12(100)$ & - & - \\
\hline$\frac{\text { Salvelinus }}{\text { fontinalis }}$ & $37(87)$ & $30(100)$ & $17(88)$ & $23(91)$ \\
\hline$\frac{\text { Salvelinus }}{\text { alpinus }}$ & - & - & $3(100)$ & $17(100)$ \\
\hline$\frac{\text { Salvelinus }}{\text { namaycush }}$ & - & - & $11(100)$ & - \\
\hline$\frac{\text { Coregonus }}{\text { clupeaformis }}$ & - & - & - & - \\
\hline$\frac{\text { Prosopium }}{\text { cylindraceum }}$ & - & - & - & - \\
\hline Total & 59 & 66 & 31 & 40 \\
\hline
\end{tabular}
a - * - freshwater; ** estuarine; *** marine.
b - includes two adult salmon ( 2 years in the sea) from Eagle River
c - does not include two Salvelinus fontinalis, three Coregonus clu 
Figure 1. Sampling areas:

1. St. Mary's River

2. Eagle River

3. Nain

4. Grand Lake

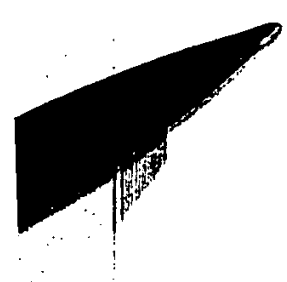




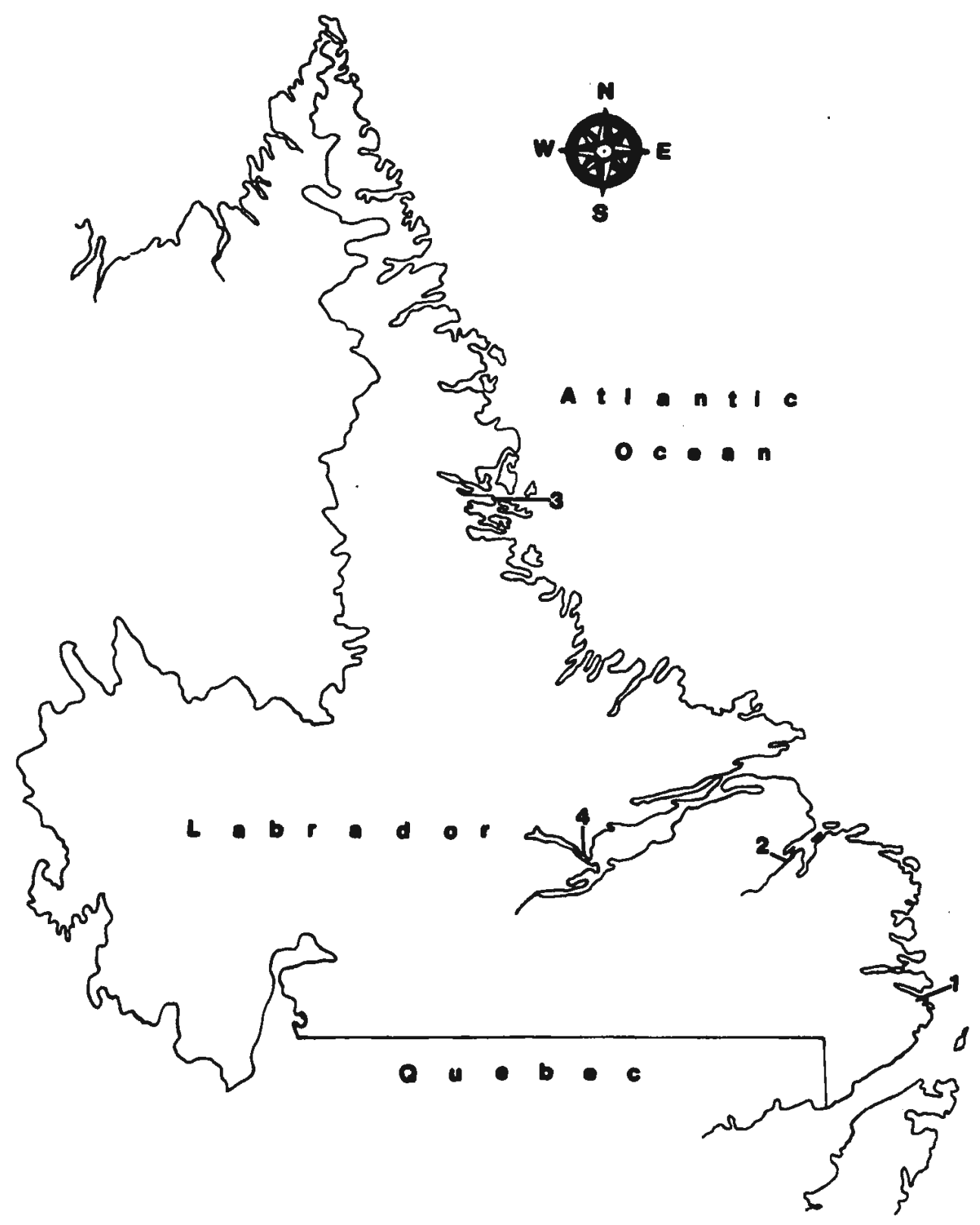


Results and Discussion

$323 \mathrm{fish}$ of 6 species were examined, parasites belonging to 24 genera ( 3 of Monogenea, 8 of Digenea, 5 of Cestoda, 5 of Nematoda, 1 of Acanthocephala, 2 of parasitic Copepoda) being recovered (Table 2). Table 3 details the sites of infection with the various parasites found in the species of salmonids and coregonids autopsied.

Salmo salar Iinnaeus, Atlantic salmon, salmon, ouananiche, black salmon, grilse, kelt.

Salmo salar yielded 14 genera of metazoan parasites (1 of Monogenea, 6 of Digenea, 3 of Cestoda, 3 of Nematoda, 1 of Acanthocephala). Details of infection with these metazoan parasites may be found in Table 4 .

Discocotyle sagittata (Leuckart, 1842) a monogenetic gill parasite common on salmonids from Europe (vide Hoffman, 1967) and $\underline{\text { s. Salar }}$ of the ejastern Atlantic coast of Canada (Pippy, MS., 1969) was recorded from s. salar (parr) from st. Mary's River and Eagle River. Sandeman and Pippy (1967) recovered Discocotyle salmonis Shaffer, 1916, from Salvelinus

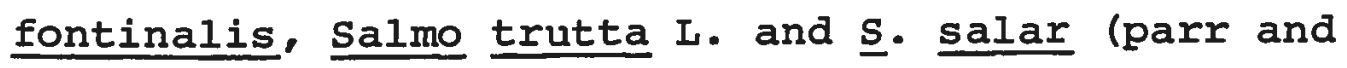
landlocked). 
Table 2. Details of infection of salmo salar, Salvelinus fontinalj clupeaformis and Prosopium cylinåraceum, with metazoan par

Species

Salmo salar $\quad$ Salvelinus $\quad \underline{\text { Santinalis }}$

$\begin{array}{lllllll}a^{a} & b^{b} & c^{c} & a & b & c & a\end{array}$

Gyrodactylus sp.

Tetraonchus variabilis

Mizelle and Webb.

1953

Discocotyle sagittat

(Leuckart, 1842)

Diesing, 1850

Podocotyle atomon

(Rud., 1802)

Bunodera luciopercae (Miller, 1776)

Crepidostomum farionis (Muller, 1784)

Diplostomum spathaceum

(Rud., 1819)

$\frac{\text { Phyllodistomum limnosa }}{\text { Sandeman and }}$ 1967

Derogenes varicus (Mửller, 1784 )

Lecitthaster gibbosus (Rud., 1802)

Brachyphallus crenatus (Rud., 1802)

Unidentified Allocrea-. diids

$\begin{array}{lllllll}7.0 & 2 & 2.0 & 11.0 & 1-31 & 6.4 & 10.0\end{array}$

- $\quad-\quad-$

1

2

$2.0-$

$35.0 \quad 1-95 \quad 11.4 \quad 51.0$

$1-610 \quad 54.5$

22.0

$17.0 \quad 1-13$

3.8

34.0

$1-280$

11.3

39.0

$1-11 \quad 5.0 \quad 26$

$1-200$

48.1

39

-

- 6

$1-165 \quad 40.1$

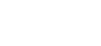

sa 
Table 2. Details of infection of Salmo salar, Salvelinus fontinal: clupeaformis and Prosopium cylindraceum, with metazoan pai

Species

Salmo salar

\begin{tabular}{|c|c|c|c|c|c|c|c|}
\hline spectes & $a^{a}$ & $b^{b}$ & $c^{c}$ & a & $b$ & c & a \\
\hline Dibothriocephalus sp. & - & - & - & 2 & 1 & 1.0 & - \\
\hline$\underline{\text { Hepatoxy }} \frac{1 \text { on }}{(\text { Holten, }} 1 \frac{\text { richiuri }}{802)}$ & 3 & 1 & 1.0 & - & - & - & - \\
\hline$\frac{\text { Proteocephalus }}{\text { tumidocolius }}$ & - & - & - & 4 & $1-5$ & 3.0 & 10 \\
\hline$\frac{\text { Proteocephalus }}{\text { (Type }} \mathrm{sp}$. & 3 & 1 & 1.0 & 11 & $1-29$ & 4.0 & 10 \\
\hline$\frac{\text { Proteocephalus }}{\text { (Type }} \mathrm{sp}$. & - & - & - & 11 & $1-125$ & 13.7 & 48 \\
\hline$\frac{\text { Capillaria }}{\text { Polyanski }} \frac{\text { salvelini }}{1952}$ & - & - & - & 7 & $1-17$ & $4 \cdot 5$ & 55 \\
\hline$\frac{\text { Contracaecum aduncum }}{\text { (Rud., } 1802)}$ & 3 & $2-3$ & 2.5 & - & - & - & 3 \\
\hline Contracaecum sp. & - & - & - & 1 & 2 & 2.0 & - \\
\hline Anisakis sp. & 53 & $1-9$ & 3.8 & 4 & $1-3$ & 1.8 & - \\
\hline 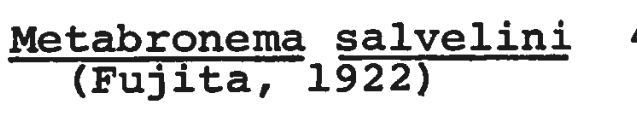 & 43 & $1-71$ & 13.4 & 39 & $1-90$ & 16.4 & 29 \\
\hline$\frac{\text { Philonema }}{\text { simon and Simon, } 1936}$ & $\frac{n-}{n}$ & - & - & 7 & $1-6$ & $2 \cdot 5$ & 7 \\
\hline Nematoda immature & - & - & - & 3 & $1-17$ & $5 \cdot 3$ & 16 \\
\hline$\frac{\text { Acanthocephalus }}{\text { Ia.Eeralis }}$ & 13 & $1-17$ & 5.1 & 50 & $1-168$ & 19.6 & 26 \\
\hline $\begin{array}{l}\text { Ergasilus } \\
\text { luciopercarum } \\
\text { Henderson, } 1926\end{array}$ & - & - & - & - & - & - & - \\
\hline$\frac{\text { salmincola edwardsii }}{\text { (Olsson, }}$ & - & - & - & 18 & $1-46$ & 4.9 & - \\
\hline$\frac{\text { Salmincola }}{(\text { Ressler }}, \frac{\text { extensus }}{1868)}$ & - & - & - & - & - & - & - \\
\hline$\frac{\text { Salmincola }}{(\text { thessler }}, \frac{\text { thymalli }}{1868)}$ & - & - & - & - & - & - & - \\
\hline
\end{tabular}

Salvelinus

fontinalis

$\underline{\text { Sa. }}$ $\underline{\text { nar }}$

$a^{a}$ - percentage; $b^{b}$ - range numbers per infected fish; $c^{c}$ - averal 
tinalis, Salvelinus namaycush, Salvelinus alpinus, Coregonus ian parasites, from coastal Labrador. (Contd.)

\begin{tabular}{|c|c|c|c|c|c|c|c|c|c|c|c|}
\hline & \multicolumn{2}{|c|}{$\frac{\text { Salvelinus }}{\text { namaycush }}$} & \multicolumn{3}{|c|}{$\frac{\text { Salvelinus }}{\text { alpinus }}$} & \multicolumn{3}{|c|}{$\begin{array}{l}\text { Coregonus } \\
\text { Clupeaformis }\end{array}$} & \multicolumn{3}{|c|}{$\frac{\text { Prosopium }}{\text { Cylindraceum }}$} \\
\hline $\mathbf{a}$ & $\mathbf{b}$ & $c$ & $a$ & $b$ & $c$ & a & $\mathbf{b}$ & $c$ & $a$ & $b$ & $c$ \\
\hline - & - & - & - & - & - & - & - & - & - & - & - \\
\hline - & - & - & - & - & - & - & - & - & - & - & - \\
\hline 0 & $1-29$ & 11.3 & 14 & $3-12$ & 8.8 & 7 & $3-17$ & 10.0 & - & - & - \\
\hline 0 & $1-8$ & 5.0 & 3 & 1 & 1.0 & 13 & $4-17$ & 8.8 & - & - & - \\
\hline 8 & $1-67$ & 17.3 & 29 & $1-24$ & 8.9 & 40 & $1-20$ & 7.3 & 3 & 1 & 1.0 \\
\hline 5 & $1-300$ & 48.0 & 3 & 10 & 10.0 & 3 & 1 & 1.0 & 7 & $1-2$ & 1.5 \\
\hline 3 & 2 & 2.0 & 3 & 5 & 5.0 & - & - & - & - & - & - \\
\hline- & - & - & 3 & 1 & 1.0 & - & - & - & - & - & - \\
\hline - & - & - & 9 & 1 & 1.0 & - & - & - & - & - & - \\
\hline 3 & $I-100$ & 32.0 & 3 & 1 & 1.0 & 3 & 7 & 7.0 & - & - & - \\
\hline 7 & $i-2$ & 1.5 & 20 & $1-5$ & 2.1 & 3 & 1 & 1.0 & 10 & $1-3$ & 1.7 \\
\hline j & $1-7$ & 3.4 & 3 & 4 & 4.0 & - & - & - & 17 & $1-9$ & 3.4 \\
\hline ; & $1-5$ & 2.5 & 26 & $1-2$ & 1.4 & 3 & 1 & 1.0 & 10 & $1-6$ & 3.0 \\
\hline - & - & - & - & - & - & - & - & - & 7 & $1-10$ & 5.5 \\
\hline - & - & - & 1 & $1-15$ & 4.8 & - & - & - & - & - & - \\
\hline . & - & - & - & - & - & 13 & $1-3$ & 1.5 & - & - & - \\
\hline . & - & - & - & - & - & - & - & - & 27 & $1-2$ & 1.3 \\
\hline
\end{tabular}

average number per infected fish. 
Table 3. Checklist of parasitofauna, with location of inf alpinus, Salvelinus namaycush, Coregonus clupea

Species

Salmo salar $\frac{\text { Salvelinus }}{\text { fontinalis }}$

Gyrodactylus sp.

Tetraonchus variabilis

Discocotyle sagittata

Podocet:yle atomon

Bunodera Iuciopercae

Crepidostomum farionis

Diplostomum spathaceum

Phyllodistomum limnosa

Derogenes varicus

Lecithaster gibbosus

Brachyphallus crenatus

Unidentified allocreadiids

Bothrimonus sturionis

Eubothrium salvelini

Eubothrium crassum

Eubothrium sp.

Dibothriocephalus sp.

Hepatoxylon trichiuri

Proteocephalus tumidocollus

Proteocephalus sp. (Type I)

Proteocephalus sp. (Type II)

Capillaria salvelini

Contracaecum aduncum

Contracaecum sp.

Anisakis sp.

$\begin{array}{cc}- & 6 \\ - & 6 \\ 6 & 6 \\ - & 3 \\ 1,2,3,4 & 1,2,3,4 \\ 2,4,10 & 2,3,4,10 \\ 5 & 5 \\ - & 9 \\ 1,4 & 1,10 \\ 2,3,4 & - \\ 1,2 & 1,2 \\ - & 2,3,4 \\ - & 2,4,4 \\ - & 2,4 \\ 2,3,4 & - \\ 3,4 & 2 \\ - & 7 \\ 4 & - \\ - & 2,3 \\ 4 & 3,4 \\ - & 2,3 \\ - & 3,4 \\ 4 & - \\ - & 7 \\ 7 & 7\end{array}$

Locations: 1 - Stomach; 2 - pyloric caeca; 3 - intestine 6 - gills; 7 - body cavity; 8 - liver; 9 - kic 11 - fins; 12 - oral cavity (opercula). 
ocation of infection, of Salmo salar, Salvelinus fontinalis, Salvelinus regonus clupeaformis and Prosopium cylindraceum from coastal Labrador.

\begin{tabular}{llll}
\hline Salvelinus & Salvelinus & Salvelinus & Coregonus \\
fontinalis & namaycush & Prosopium \\
alpinus & clupeaformis & cylindraceum
\end{tabular}

\begin{tabular}{|c|c|c|c|c|c|c|}
\hline & 6 & - & - & & - & - \\
\hline & 6 & - & - & & - & 6,12 \\
\hline & 6 & 6 & - & & 6 & 6 \\
\hline & 3 & - & - & & - & - \\
\hline 1 & $2,3,4$ & $2,3,4$ & 2 & & - & 2 \\
\hline 2, & $3,4,10$ & $2,3,4,10$ & 2,3, & 10 & 3 & - \\
\hline & 5 & 5 & 5 & & 5 & 5 \\
\hline & 9 & - & 9 & & 9 & - \\
\hline & 1,10 & - & 1 & & - & - \\
\hline & - & - & - & & - & - \\
\hline & 1,2 & $1,2,4$ & 1,2 , & 3,4 & - & - \\
\hline 2, & 3,4 & - & - & & - & - \\
\hline 2, & 3,4 & 3 & 2 , & 3 & - & - \\
\hline & 2,4 & 2 & 2 , & 3 & - & 2 \\
\hline & - & 2 & 2 , & 3 & - & - \\
\hline & 2 & 2,4 & 2,3 , & 4 & 2,3 & 2 \\
\hline & 7 & - & - & & - & - \\
\hline & - & - & - & & - & - \\
\hline & 2,3 & $2,3,4$ & 2 & & 2,3 & - \\
\hline & 3,4 & 2,4 & . 2 & & 3,4 & - \\
\hline & 2,3 & $2,3,4$ & 2,3 & 4 & $2,3,4$ & 3 \\
\hline & 3,4 & $1,2,3,4$ & 2 & & 4 & 2,3 \\
\hline & - & 4 & 2 & & - & - \\
\hline & 7 & - & 7 & & - & - \\
\hline & 7 & - & 7 & & - & - \\
\hline \multicolumn{7}{|c|}{$\begin{array}{l}3 \text { - intestine (I); } 4 \text { - intestine (II); } 5 \text { - eye (humours); } \\
\text { liver; } 9 \text { - kidney (ureter); } 10-\text { gall bladder; } \\
\text { scula). }\end{array}$} \\
\hline
\end{tabular}


Table 3. Checklist of parasitofauna, with location of infe alpinus, Salvelinus namaycush, Coregonus clupeaf (contd.).

Species
Salmo salar $\frac{\text { Salvelinus }}{\text { fontinalis }} \frac{\mathrm{s}}{\mathrm{n}}$

$\begin{array}{rc}1,2,3,4 & 1,2,3 \\ - & 7,1,2,3,4 \\ - & 2 \\ 2,3,4 & 2,3,4 \\ - & - \\ - & 6,11 \\ - & - \\ - & -\end{array}$

Locations: 1 - Stomach; 2 - pyloric caeca; 3 - intestine 6 - gills; 7 - body cavity; 8 - liver; 9 - kid 11 - fins; 12 - oral cavity (opercula).

Metabronema salvelini

Philonema agubernaculum

Nematoda immature

Acanthocephalus lateralis

Ergasilus luciopercarum

Salmincola edwardsii

Salmincola extensus

Salmincola thymalli

(1)


$n$ of infection, of Salmo salar, Salvelinus fontinalis, salvelinus $\underline{s}$ clupea formis and Prosopium cylindraceum from coastal Labrador

\begin{tabular}{|c|c|c|c|c|}
\hline$\frac{\text { linus }}{\text { nalis }}$ & $\frac{\text { Salvelinus }}{\text { namaycush }}$ & $\frac{\text { Salvelinus }}{\text { alpinus }}$ & $\begin{array}{l}\text { Coregonus } \\
\text { clupeaformis }\end{array}$ & $\begin{array}{l}\text { Prosopium } \\
\text { Cylindraceum }\end{array}$ \\
\hline 3 & 1 & 3 & 1 & - \\
\hline \multirow[t]{2}{*}{$2,3,4$} & 7 & 7,$1 ; 2$ & 1 & 7,1 \\
\hline & 1,3 & 3 & - & 8,2 \\
\hline \multirow[t]{2}{*}{4} & 3 & $2,3,4$ & 3 & $2,3,4$ \\
\hline & - & - & - & 6 \\
\hline \multirow[t]{3}{*}{11} & - & 6,12 & - & - \\
\hline & - & - & 11,12 & - \\
\hline & - & - & - & 6,11 \\
\hline
\end{tabular}

2testine (I); 4 - intestine (II); 5 - eye (humours); ; 9 - kidney (ureter); 10 - gall bladder; 
Table 4. Details of infection of Salmo salar, with metazoan pa! Eagle River, Nain and Grand Lake.

\begin{tabular}{|c|c|c|c|c|c|}
\hline \multirow{2}{*}{ Species } & \multirow{2}{*}{$\frac{\text { st. }}{a^{a}}$} & \multicolumn{2}{|c|}{ Mary's River } & \multirow[b]{2}{*}{ a } & \multirow{2}{*}{$\frac{\text { Eagle R: }}{b}$} \\
\hline & & $b^{b}$ & $c^{c}$ & & \\
\hline$\frac{\text { Discocotyle sagittata }}{\text { (Leuckart, }}$ & 14 & 2 & 2.0 & 3 & 2 \\
\hline *Bunodera $\frac{\text { luciopercae }}{(\text { Müller }}$ & 50 & $1-35$ & 7.3 & 28 & $3-95$ \\
\hline$\frac{\text { Crepidostomum farionis }}{\text { (Müller, } 178 \text { 4) }}$ & 18 & $1-2$ & 1.3 & 14 & $2-13$ \\
\hline$\frac{\text { Diplostomum }}{\text { (Rud., } 18 \text { spathaceum }}$ & - & - & - & 14 & $1-11$ \\
\hline$\frac{\text { Derogenes }}{\text { (Müller }}, \frac{\text { varicus }}{1784)}$ & 5 & 1 & 1.0 & 8 & $1-5$ \\
\hline$\frac{\text { Lecithaster gibbosus }}{\text { (Rud., 1802) }}$ & - & - & - & - & - \\
\hline$\frac{\text { Brachyphallus }}{\text { (Rud., } 1802)}$ & - & - & - & 3 & 3 \\
\hline$\frac{\text { Eubothrium }}{\text { (Bloch, } 1779)}$ & 27 & $1-25^{d}$ & 13.2 & 47 & $1-25$ \\
\hline Eubothrium sp. & 5 & 6 & 6.0 & 8 & $1-5$ \\
\hline$\frac{\text { Hepatoxylon trichiuri }}{\text { (Holten, } 1802)}$ & - & - & - & 6 & 1 \\
\hline Proteocephalus sp. (Type I) & 5 & 1 & 1.0 & - & - \\
\hline$\frac{\text { Contracaecum aduncum }}{(\text { Rud. } 1802)}$ & 9 & $2-3$ & 2.5 & - & - \\
\hline Anisakis sp. & 46 & $1-8$ & 3.6 & 58 & $1-9$ \\
\hline * Metabronema salvelini & 50 & $1-31$ & 9.1 & 42 & $1-71$ \\
\hline *Acanthocepinalus lateralis & 27 & $1-9$ & 3.5 & 3 & 3 \\
\hline
\end{tabular}

$a^{a}$ - percentage; $b^{b}$ - range numbers per infected fish; $c^{c}-a v$ d - 25 represents almost complete occlusion of the gut lumen. * new host record. 
Controversy in the literature arises over the establishment of two species of Discocotyle. In 1916, Shaffer described $\underline{D}$. Salmonis from the rainbow trout, (Salmo gairaneri Richardson), since which time this helminth has been reported from a variety of salmonid and coregonid species in North America (vide Hoffman, 1967). Many workers, however, do not agree that $D$. salmonis represents a distinct species (Price, 1943; Brinkman, 1952; Paling, 1965; Dawes, 1968). In view of the preponderance of evidence for a single species, the specimens found in the $\underline{\mathrm{s}}$. salar from Labrador are considered to be Discocotyle sagittata.

Bunodera luciopercae (Müller, 1776), found only infrequently in salmonids, has not previously been recorded from S. salar. During the present study $50 \%$ ( 8 parr, 1 smolt, 2 grilse) of these fish from st. Mary's River and 28\% (7 parr, 2 smolt, 1 grilse) from Eagle River were infected with this helminth. The presence of $B$ - Iuciopercae, a helminth characteristic of freshwater fishes (Bykhovsky et al., 1962), in grilse can only be explained if they were angled several miles upstream, where they would have had the opportunity to acquire the parasite by eating the intermediate host. Iittle or no feeding occurs in migrating grilse (Leim and scott, 1966). The parasite might also have been acquired when the fish were in estuarine or marine waters if the intermediate host was swept down into these regions. 
Metacercariae of Diplostomum spathaceum (Rud., 1819), were recovered from the aqueous and vitreous humour of S. Salar ( 148 infected) from Eagle River. Bykhovsky et al. (1962) and Skrjabin (1960) noted the presence of $\underline{D}$. spathaceum in S. salar in Europe and the U.S.S.R., while Pippy (MS., 1969) recorded Diplostomulum sp. in s. salar from the eastern coast of Canada. The recovery of $\underline{D}$. spathaceum, from $\underline{s}$. salar in Labrador greatly expands the known geographical range of this parasite.

Derogenes varicus (Müllex,1784) a parasite of marine fish (ide Hoffman, 1967; Dollfus, 1953) was found to be a common parasite of S. salar. Threlfall and Hanek (1970) working on the Avalon Peninsula of insular Newfoundland did not recover $\underline{D}$. varicus from this species, while sandeman and Pippy (1967), also working on the island noted that 298 of

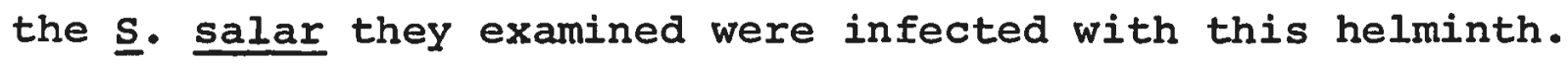
Pippy (MS. 1969) recorded a high incidence of D. varicus in S. salar from rivers in S. W. England, Greenland and the eastern coast of Canada, particularly among adult fish. Heitz (1917) found this parasite in $\underline{\mathbf{s}}$. salar, from the Rhine River, Germany, in numbers often exceeding 100. In Labrador, D. varicus was found to infect this species of fish in three of the four locations sampled. The infected fish comprised a single adult ( 2 years in the sea) and the remainder, grilse. 
Lecithaster gibbosus (Rud., 1802) was recovered

from a single grilse caught in Grand Lake. Pippy (MS., 1969) demonstrated that $\underline{I}$. gibbosus is a common parasite of s. salar (adult and grilse) in rivers along the Atlantic coast of Canada and the U.S.A. Threlfall and Hanek (1970) recovered $\underline{\text {. }}$ gibbosus from this host on the Avalon Peninsula.

Brachyphallus crenatus (Rud., 1802), a parasite of marine and anadromous fish (Hoffman, 1967), was recovered from one grilse taken in Eagle River and the single specimen from Grand Lake.

Eubothrium crassum (Bloch, 1779) was found in grilse from St. Mary's River (27\% infected) and from Eagle River ( 478 infected). The range of parasites per infected fish was $1-25$. In the cases where high numbers were seen the intestinal lumen was almost completely occluded. In a

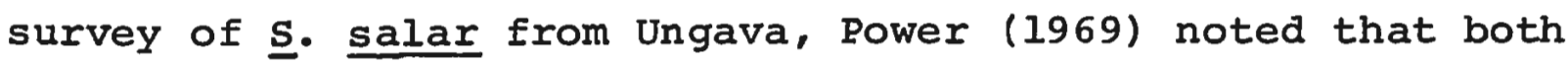
juvenile freshwater stages and adults returning from the sea were infected with this cestode. George River parr (25.48 infected) and smolts (16.5\% infected) harboured this parasite when examined in 1956. Power (op. it) also noted smaller numbers of parr were recovered with $\underline{E}$. crassum in studies of the Koksoak River, 1957 (4.4\% infected) and Whale River, 1960 ( $1.8 \%$ infected). These surveys are in contrast with the findings of Pippy (MS., 1969) and the 
present study, where E. Crassum was recovered only in S. salar that had been to the sea. Sandeman and Pippy (1967) were unable to make positive identification for lack of mature specimens, despite the large size of the worms. This is a problem that became apparent in the present study.

Kennedy (1969) presents a plausible account of the occurrence of E. crassum in S. salar and Salmo trutta of the River Exe, Devon, England. He found that parasites present in s. salar and sea trout (migratory $\underline{s}$. trutta) migrating upstream ranged in size from small and imnature to large and mature, though rarely gravid. The loss of gravid worms in the sea prior to entry into the river would explain the presence of very large but immature forms in the $\underline{s}$. salar collected by Sandeman and Pippy (1967) and in the present study. Kennedy's (1969) results show a high incidence of infection with $\underline{E}$. crassum in returning adult $\underline{\text { s. salar but }}$ complete absence in smolts, which would indicate that this cestode is acquired in the sea. Its presence, however, in sea trout where the cestode continues to grow led kennedy to suggest the existence of two biological races of E. Crassum, a marine and a freshwater one. The present results support the above theory.

Plerocercoids of Hepatoxylon trichiuri (Holten, 1802) were found in two grilse ( 1 per infected host) from 
Eagle River. Dollfus (1942) lists the definitive hosts, elasmobranchs, of this helminth and its geographical distribution. Pippy (MS. 1969) found the incidence of H. trichiuri to be high in $\underline{s}$. salar from Greenland and suggested that its presence in a fish caught in Canadian waters, might indicate that the fish in question had travelled to the Greenland sea and back during its time at sea.

\section{Proteocephalus sp. (Type I), an immature tapeworm} with a scolex bearing an apical disk, was recovered on one occasion from a St. Mary's River grilse. This form with an apical disk was designated proteocephalus sp. (Type I) in contrast to Proteocephalus sp. (Type II), which lacks such a structure and which was found in the remainder of the salmonids and one coregonid species.

Anisakis sp. larvae, common in marine teleosts (Berland, 1961), have been recovered from $\underline{\text { s. salar }}$ in the U.S.S.R. (vide Bykhovsky et al., 1962) and from the Atlantic coast of Canada (Pippy, MS., 1969). Neither Sandeman and Pippy (1967) in their survey of insular Newfoundland nor Threlfall and Hanek (1970) on the Avalon Peninsula recorded the presence of this larval nematode. Always found encysted and coiled in a flat spiral (Berland,1961b), Anisakis sp.

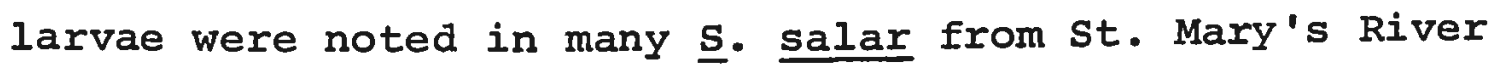
(46\% infected) and Eagle River (58\% infected). 
Significant differences were noted in the incidence of infection and sex of the fish host in the case of B. Iuciopercae $(P<.05)$ and $E$. crassum $(P<.005)$. Female S. salar, predominantly parr, were found to be infected more than males by B. luciopercae (55\% of females infected, $21 \%$ of males infected). In contrast, E. crassum occurred more frequently in males, predominantly grilse ( 98 of females, $58 \%$ of males). The reasons for these differences are unclear, but may be a reflection of subtle differences in mode of feeding, habitat or behaviour of the sexes.

The distribution of Acanthocephalus lateralis in S. Salar throughout Labrador was not homogeneous $(P<.005)$, a greater percentage of $\underline{s}$. salar (parr) from st. Mary's River being infected than from the other locations sampled (Table 4).

A gradual increase in the incidence of parasites with growth of $\underline{\text { s. Salar }}$ (parr) (Table 5) typifies the rule of age dynamics put forward by Dogiel (1958). He postulated that the age of the fish can be correlated with incidence and intensity of infestation. Further, he noted a decrease in the parasitofauna upon entry of the anadromous fish into freshwater, a phenomenon also illustrated in Table 5. Heitz (1917) noted that $\underline{S}$. salar gradually lose the intestinal parasites they acquired in the sea as they move into freshwater, the decrease being proportional to the duration of the journey and the distance travelled. 
Table 5. Relationship between the number of parasite species and age of Salmo salar (Figures in the body of the table show the percentage of fish in an age class).

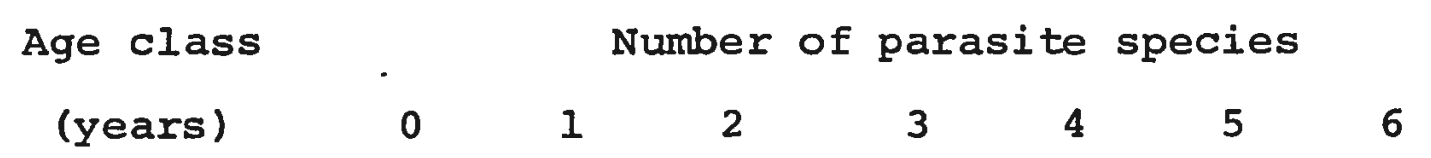

Freshwater

$\begin{array}{rrrrrrrr}0-1 & - & - & - & - & - & - & - \\ 1-2 & - & - & 100 & - & - & - & - \\ 2-3 & - & - & 40 & 60 & - & - & - \\ 3-4 & - & 17 & 17 & 49 & 17 & - & - \\ 4-5 & - & - & 33 & - & 67 & - & - \\ 5-6 & - & - & - & - & 67 & 33 & -\end{array}$

Marine

$\begin{array}{rrrrrrrr}4-5 & - & - & 50 & - & - & - & 50 \\ 5-6 & - & 20 & 50 & 30 & - & - & - \\ 6-7 & - & 29 & 29 & 42 & - & - & - \\ 7-8 & - & - & 100 & - & - & - & -\end{array}$


Salvelinus fontinalis (Mitchill), brook trout, mud trout, speckled trout, coaster, truite de mer, truite mauchetee.

\section{Salvelinus fontinalis, numerous in all four}

sampling areas, contained the most diverse parasitofauna of all the species of fish examined (21 genera of parasites including 3 of Monogenea, 7 of Digenea, 4 of Cestoda, 5 of Nematoda, 1 of Acanthocephala, 1 of parasitic Copepoda). Details of infection with these metazoan parasites may be seen in Table 6 .

A single specimen of Gyrodactylus sp. (Figure 2) was recovered from the gills of a fish caught in Grand Lake. The present specimen resembles most closely $G$. salmonis which was described as G. elegans (var. B) from Brook trout by Mueller (1936). Yin and Sproston (1948) synonymized Mueller's G. elegans (var. B) with $\underline{G}$. elegans salmonis which they described. Malmberg (1956) gave this parasite full specific status, Gyrodactylus salmonis. Morphological criteria of $\underline{G}$. salmonis and the Labrador specimen are given in Table 7.

Tetraonchus variabilis Mizelle and Webb, 1953, was

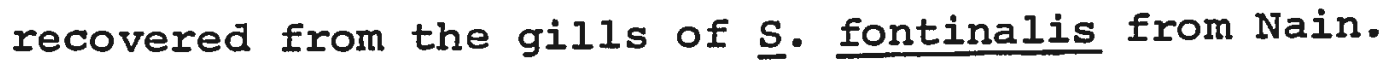
Bykhovsky et al. (1962) and Hoffman (1967) record various Tetraonchids from salmonids, however, $\underline{T}$. variabilis has not previously been recorded from this host. 
Table 6. Details of infection of Salvelinus fontinalis, wit River, Nain and Grand Lake (conta.).

\begin{tabular}{|c|c|c|c|c|c|}
\hline \multirow{2}{*}{ Species } & \multirow{2}{*}{$\frac{s t .}{a^{a}}$} & Mary's & \multirow{2}{*}{$\frac{\text { River }}{\mathbf{c}^{\mathbf{c}}}$} & \multicolumn{2}{|c|}{ Eagle } \\
\hline & & $b^{b}$ & & $a$ & k \\
\hline Proteocephalus sp. (Type I) & - & - & - & 7 & $3-$ \\
\hline Proteocephalus sp. (Type II) & - & - & - & - & - \\
\hline 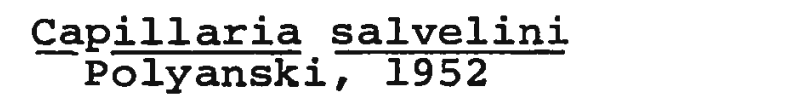 & - & - & - & 10 & 3- \\
\hline Contracaecum sp. & - & - & - & 3 & 2 \\
\hline *Anisakis sp. - & - & - & - & 17 & $1-$ \\
\hline$\frac{\text { Metabronema }}{\text { (Fujita, }} \frac{\text { salvelini }}{922)}$ & 60 & $1-22$ & 6.0 & 87 & 4- \\
\hline$\frac{\text { Philonema agubernaculum }}{\text { Simon and }}$ & - & - & - & 3 & 6 \\
\hline Nematoda immature & - & - & - & - & - \\
\hline$\frac{\text { Acanthocephalus lateralis }}{(\text { LeidY, }}$ & 78 & $1-168$ & 31.6 & 40 & $1-$ \\
\hline$\frac{\text { Salmincola }}{\text { (0lsson, }} \frac{\text { edwardsii }}{1869)}$ & 19 & $1-3$ & 1.4 & 43 & $1-$ \\
\hline
\end{tabular}

$$
\begin{aligned}
& a^{a}=\text { percentage; } b^{b}=\text { range numbers } \\
& c^{c}=\text { average number per infected fish } \\
& \text { * new host record. }
\end{aligned}
$$


fontinalis, with metazoan parasites, from st. Mary's River, Eagle

\begin{tabular}{|c|c|c|c|c|c|c|c|c|c|}
\hline \multirow{2}{*}{$\frac{. \text { ver }}{c}$} & \multicolumn{3}{|c|}{ Eagle River } & \multicolumn{3}{|c|}{ Nain } & \multicolumn{3}{|c|}{ Grand Lake } \\
\hline & $a$ & $b$ & c & $a$ & $\mathrm{~b}$ & c & $a$ & $b$ & $c$ \\
\hline - & 7 & $3-5$ & 4.0 & - & - & - & 17 & $1-29$ & 13.0 \\
\hline- & - & - & - & - & - & - & 50 & $1-125$ & 13.7 \\
\hline - & 10 & $3-17$ & 10.3 & 8 & $2-6$ & 4.0 & 13 & $1-4$ & 3.0 \\
\hline - & 3 & 2 & 2.0 & - & - & - & - & - & - \\
\hline - & 17 & $1-3$ & 1.8 & - & - & - & - & - & - \\
\hline .0 & 87 & $4-90$ & 28.4 & - & - & - & 20 & $1-8$ & 2.8 \\
\hline - & 3 & 6 & 6.0 & 3 & 2 & 2.0 & 27 & $1-6$ & 2.1 \\
\hline - & - & - & - & 5 & $1-17$ & 9.0 & 7 & $1-2$ & 1.5 \\
\hline .6 & 40 & $1-72$ & 15.6 & 43 & $1-16$ & 4.7 & 37 & $1-34$ & 15.5 \\
\hline .4 & 43 & $1-46$ & 8.1 & 5 & 1 & 1.0 & 7 & $I$ & 1.0 \\
\hline
\end{tabular}

range numbers per infected fish;

infected fish. 
Figure 2. Anchors and marginal hook of Gyrodactylus sp. from Salvelinus fontinalis from coastal Labrador. 

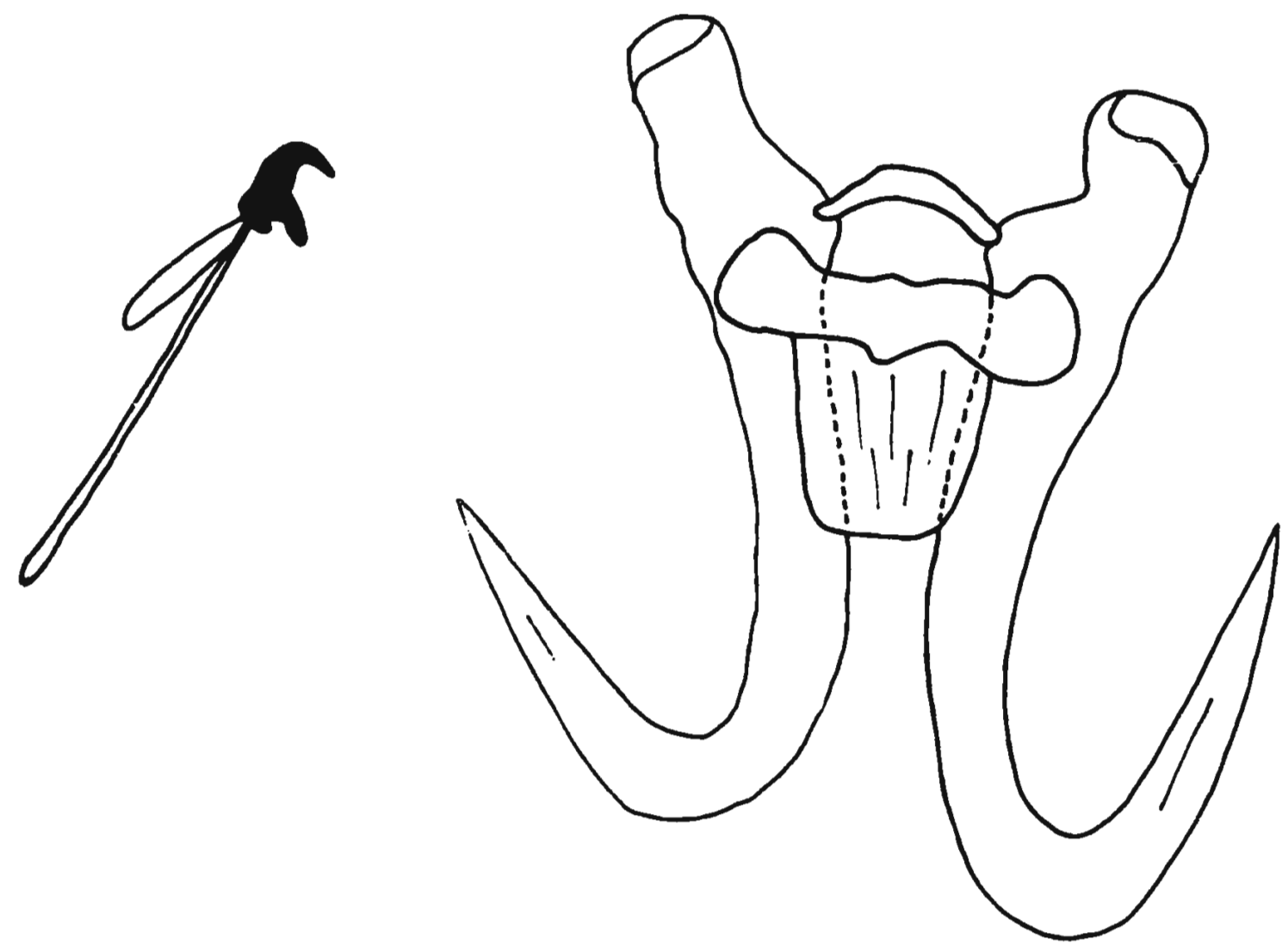

$0.014 \mathrm{~mm}$ 
Table 7. Measurements (microns) of Gyrodactylus sp. recovered from Salvelinus fontinalis and comparis on with Gyrodactylus elegans (var. B) Mueller, 1936.

Morphological criteria

Labrador

(1 specimen)
Gyrodactylus elegans

(Var. B) Mueller, 1936

\begin{tabular}{|c|c|c|}
\hline *Length of anchors & $64-65$ & $65-70$ \\
\hline *Length of basal part & $50-55$ & - \\
\hline *Length of point & $31-30$ & 32 \\
\hline *Length of inner root & $18-17$ & - \\
\hline $\begin{array}{l}\text { Width of principal } \\
\text { connecting bar }\end{array}$ & 29 & 25 \\
\hline $\begin{array}{l}\text { Length of principal } \\
\text { connecting bar - midale }\end{array}$ & 6 & - \\
\hline $\begin{array}{l}\text { Length auxillary connecting } \\
\text { bar }\end{array}$ & 2 & - \\
\hline $\begin{array}{l}\text { Width auxillary connecting } \\
\text { bar }\end{array}$ & 19 & - \\
\hline $\begin{array}{l}\text { Length of marginal hook and } \\
\text { shaft }\end{array}$ & 45 & 48 \\
\hline Length of marginal hook & 8 & 8 \\
\hline Length of membranoid extension & 13 & 25 (approx.) \\
\hline Body length & 750 & $400-450$ \\
\hline Length of pharynx & 49 & 37 (Diam.) \\
\hline Width of pharynx & 41 & - \\
\hline Length of cirrus & 15 & $13-17$ (Diam.) \\
\hline Width of cirrus & 12 & - \\
\hline
\end{tabular}

* Two values for indicated criteria represent left and right components. 
Bykhovsky et al. (1962) reported that Podocotyle atomon (Rud., 1802) is a common digenean of salmonids in the U.S.S.R., whereas in North America it has only been recorded from salmo salar (Stafford, 1904). Shaw (1947; vide Hoffman, 1967) noted Podocotyle sp. from Cutthroat trout ( oregon. The two specimens seen in a fish from st. Mary's River constitute a new North American host record. Proximity to brackish water increases the chances of infection with this predominantly marine species (Linton, 1940; vide Hoffman, 1967; vide Bykhovsky et al., 1962). Hanek and Threlfall (1970 a, b) recovered $\underline{\mathrm{P}}$. atomon from three spine sticklebacks (Gasterosteus aculeatus L.) and American eels (Anguilla rostrata (LeSueur)) taken in St. Mary's River and the estuary at Mary's Harbour.

Metacercariae of Diplostomum spathaceum, common in North American fish (vide Hoffman, 1967), has not, before, been recorded from salvelinus fontinalis. Its presence in this fish in 3 out of 4 locations sampled on the Labrador coast represents a new host record for North America. Threlfall (1968 a, b) showed that adult D. spathaceum are present in Newfoundland coastal birds. Neither Sandeman and Pippy (1967), nor Threlfall and Hanek (1970) recovered Diplostomulum spp. in their surveys of the salmonid and coregonid species from insular Newfoundland. 
Derogenes varicus was found in both sea-run and river dwelling trout from Eagle River and Grand Lake. The sea-run individuals (11) exhibited pale coloration and heavy growth, characteristic of trout recently returned from the sea (Leim and scott, 1966). The presence of D. varicus, a trematode of marine and/or anadromous fish ( vide Bykhovsky et al., 1962; vide Hoffman, 1967), in s. fontinalis constitutes a new host record for North America.

Brachyphallus crenatus, a digenean of both marine and freshwater fishes (vide Hoffman, 1967) and common in salmonid species from the U.S.S.R. (vide Bykhovsky et al., 1962), British Columbia (Bangham and Adams, 1954) and eastern Canada (Miller, 1941) has not, previous: to the present work, been recorded from $\underline{s}$. fontinalis.

Sandeman and Pippy (1967) recovered Dibothriocephalus sp. plerocercoids from $\underline{S}$. fontinalis caught in insular Newfoundland, this species of helminth being noted in 2 fish from Eagle River (1 plerocercoid/host - body cavity). Hoffman (1967), Wardle and McLeod (1952), cite numerous references in which fish, including $\underline{S}$. fontinalis act as intermediate hosts for Dibothriocephalus spp. Threlfall (1968 a, b; 1969) and Smith (unpubl. M.Sc., 1970) have recovered three species of Diphyllobothrium from various mammals and birds in insular Newfoundland. 
Proteocephalus tumidocollus Wagner, 1953 (Figure 3a, Table 8), a tapeworm described from Salmo gairdneri and Salvelinus fontinalis taken in California (Wagner, 1953) was

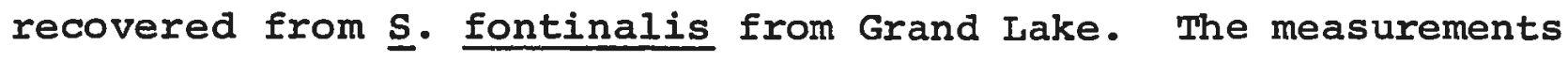
of the Labrador specimens agree closely with those of Wagner (1953) with the following exceptions: (1) a smaller number of lateral uterine diverticula, (2) slightly larger suckers and apical disk, (3) shorter neck, (4) overall size somewhat smaller. The slight differences in size may be a response to geographical factors affecting growth and maturity, both of host and parasite. These discrepancies are not thought sufficient to form the basis of a new species description.

A closely related species, $\underline{\text {. parallacticus, }}$ originally described from Salvelinus namaycush (MacLulich,

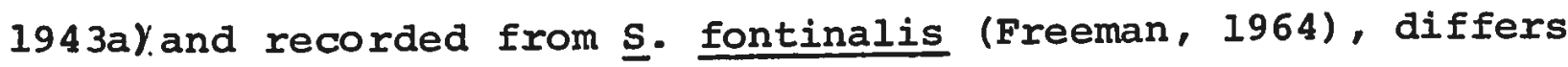
from $\underline{P}$. tumidocollus by having a larger apical fifth sucker $(0.06 \times 0.03 \mathrm{~mm})$, longer and wider cirrus sac and larger testes. These latter two organs are approximately twice as large as corresponding organs in $\underline{P}$. tumidocollus. Various other proteocephalids, either closely resembling $\underline{\underline{p}}$ - tumidocollus or reported from $\underline{\mathbf{s}}$. fontinalis include $\underline{\underline{P}}$. arcticus cooper, 1921 (vide Freze, 1965), ‥ pinguis La Rue, 1911 (vide Freze, 1965) and $\underline{P}$. pusillus Ward, 1910 (vide Freze, 1965).

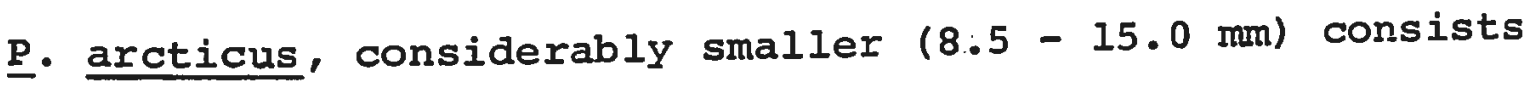
of 15 - 20 proglottids and the functional suckers, the cirrus 
Figure 3. Scoleces of (a) Proteocephalus tumidocollus, (b) Proteocephalus sp. (Type II) and (c) Proteocephalus sp. (Type I) recovered from Salvelinus fontinalis from coastal Labrador. 

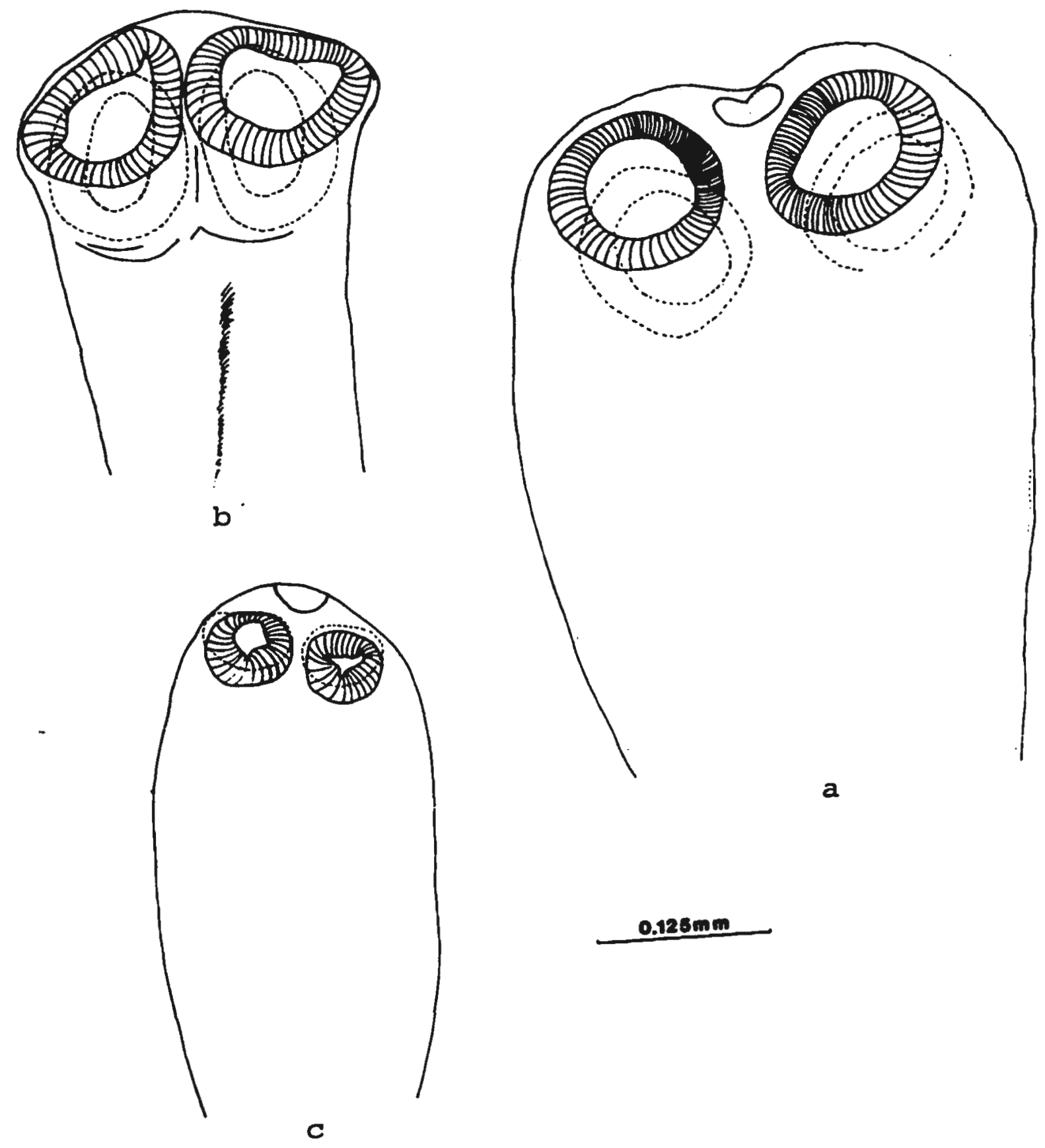

a

$0.126 \mathrm{~mm}$ 
Table 8. Measurements (microns, unless indicated otherwise) of and comparison with type specimens of Wagner, 1953.

\begin{tabular}{|c|c|c|}
\hline \multirow[t]{2}{*}{ Morphological criteria } & \multicolumn{2}{|c|}{$\begin{array}{l}\text { Labrador } \\
\text { (16 specimens in balsam }\end{array}$} \\
\hline & Average & Range \\
\hline strobila - length (mm.) & 12 & $4-28$ \\
\hline - width (mm.) & .6 & $.4-.9$ \\
\hline Proglottids - immature - length & 270 & $153-400$ \\
\hline - width & 433 & $300-600$ \\
\hline - mature - length & 522 & $380-700$ \\
\hline - width & 517 & $369-680$ \\
\hline - gravid - length & 698 & $570-850$ \\
\hline - width & 662 & $55 \theta-850$ \\
\hline Scolex - length to proglottid & 1256 & $900-1900$ \\
\hline - width & 315 & $230-430$ \\
\hline Suckers - diameter & 143 & $112-160$ \\
\hline - apical & 63 & $44-96$ \\
\hline Testes - length & 52 & $45-70$ \\
\hline - width & 37 & $36-41$ \\
\hline - number/proglottid & 45 & $30-50$ \\
\hline Cirrus pouch - length & 246 & $170-278$ \\
\hline - width & 67 & $40-85$ \\
\hline $\begin{aligned} & * E g g \text { diameter - } \text { inner membrane } \\
& \text { enclosing oncosphere }\end{aligned}$ & 20 & $15-22$ \\
\hline Ovary - length & 101 & $70-144$ \\
\hline - width - total & 332 & $230-480$ \\
\hline - individual lobes & 140 & $108-190$ \\
\hline Uterine diverticula & 7 & $5-8$ \\
\hline
\end{tabular}

* Egg measurements are intrauterine. 
sac and vas deferens are approximately twice as large. P. pinguis, common in Esocidae (Freze, 1965) has been

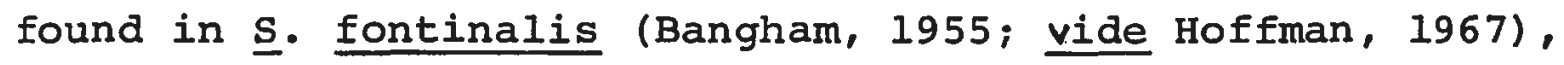
but differs from $\underline{p}$. tumidocollus in the smaller size of the functional suckers $(0.06-0.07 \mathrm{~mm})$, with the exception of the apical fifth sucker which is larger $(0.05-0.075 \mathrm{~mm})$. Similarly, $\underline{\mathbf{p}}$. pusillus recovered from $\underline{\mathbf{s}}$. fontinalis (Meyer, 1954 ) and $\underline{s}$. namaycush (MacLulich, 1943b) contains a smaller cirrus pouch $(0.095-0.106 \times 0.053-0.060 \mathrm{~mm})$ and bears larger suckers $(0.14-0.11 \mathrm{~mm})$, including the apical sucker $(0.060 \mathrm{~mm})$.

\section{Proteocephalus sp. (Type I), bearing an apical} disk (Figure 3c), was present in s. fontinalis. All the specimens of this type were immature precluding specific diagnosis. However, the presence of the apical disk suggests that this is an immature form of $\underline{P}$. tumidocollus. Specimens of Proteocephalus sp. (Type II), present in S. fontinalis (50\% infected) from Grand Lake, differ from Type I in that they lack an apical disk (Figure 3b). Morphological criteria of proteocephalus sp. Type I and II are presented in Table 9 for comparison.

Larval Anisakis sp., a common helminth of anadromous fish (vide Hoffman, 1967), were found in Eagle River s. fontinalis ( $17 \%$ infected), this report constituting a new host record. 
Table 9. A comparison of morphological characteristics of the two forms of Proteocephalus sp. recovered from Salvelinus fontinalis from Labrador.

\begin{tabular}{lcccc}
\hline $\begin{array}{c}\text { Morphological } \\
\text { criteria }\end{array}$ & $\begin{array}{c}\text { Type I } \\
\text { Average }\end{array}$ & $\begin{array}{c}\text { Proteocephalus sp. } \\
\text { specimens) } \\
\text { Range }\end{array}$ & $\begin{array}{c}\text { Type II } \\
\text { Average }\end{array}$ & $\begin{array}{c}\text { specimens } \\
\text { Range }\end{array}$ \\
\hline $\begin{array}{l}\text { Total length } \\
\text { Maximum width } \\
\text { (behind scolex) }\end{array}$ & 644 & $425-1200$ & 1620 & $900-2430$ \\
$\begin{array}{l}\text { Length of sucker } \\
\begin{array}{l}\text { Width of sucker } \\
\text { Diameter of apical }\end{array}\end{array}$ & 60 & $81-173$ & 242 & $180-315$ \\
disk & 58 & $53-68$ & 144 & $125-200$ \\
& 30 & $13-40$ & 100 & $75-125$ \\
\end{tabular}


The parasitic copepod, Salmincola edwardsii was identified from fish taken in Eagle River (43\% infected) and St. Mary's River (198 infected). Sandeman and Pippy (1967) described s. exsanguinata from this host; Kabata (1969) synonymized exsanguinata with $\underline{\text { s. edwardsii. }}$

No significant differences were noted when the total parasitofauna of male and female $\underline{\text { s. fontinalis was }}$ examined. However, a significant difference $(P<.05)$ was evident in the incidence of infection of males and females with Diplostomum spathaceum. Metacercariae of this trematode, occurring in the humours of the eye, were present in $16 \%$ of the males examined $(6 / 37)$ and 388 of the females $(28 / 74)$.

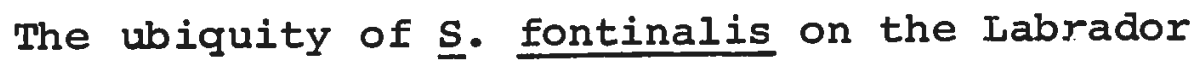
coast afforded the opportunity of examining the pitch of parasitism in various locations. The metazoan parasites, Bunodera Iuciopercae, Crepidostomum farionis, Diplostomum spathaceum, Brachyphallus crenatus, Metabronema salvelini and Salmincola edwardsii each exhibited significant differences $(P<.005)$. in their incidence in the various locations sampled (Table 6). The mode of feeding, habitat, migrations, and behaviour of the fish host and the presence of the proper intermediate host are factors that are important when considering the distribution of a particular parasite. Life cycle studies would perhaps provide important clues to these biological anomalies. 
It was noted that as $\underline{s}$. fontinalis aged, there was a corresponding increase in the number of parasites (Table 10), clearly indicating that this fish species follows Dogiel's postulate of age dynamics.

Salvelinus namaycush (Walbaum), Lake trout, Kokomish, namaycush, mackinaw trout, grey trout, togue and landlocked salmon.

Twelve genera of metazoan parasites were identified from twenty one $\underline{s}$. namaycush examined ( 1 of Monogenea, 4 of Digenea, 2 of Cestoda, 4 of Nematoda, 1 of Acanthocephala). No parasitic copepods were found. Details of infection with these metazoan parasites are shown in Table 11.

Discocotyle sagittata, not previously recorded

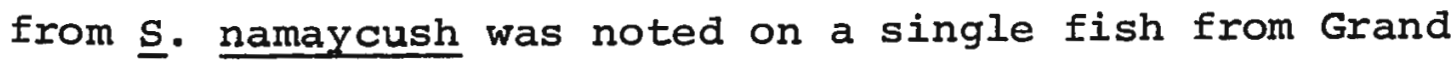
Lake.

\section{Bunodera luciopercae was recovered from this} species taken at Nain (27웅 infected) and in Grand Lake (20\% infected). Although the percentage of fish infected in each location is similar, a marked difference exists in the pitch of parasitism, those from Nain being far more heavily infected than those from Grand lake (average number of this helminth/infected fish 52:2, range of numbers/infected fish 
Table 10. Relationship between the number of parasite species and age of Salvelinus fontinalis (Figures in the body of the table show the percentage of fish in each age class).

\begin{tabular}{ccccccccccccc} 
Age class & \multicolumn{10}{c}{ Number of parasite species } \\
(years) & 0 & 1 & 2 & 3 & 4 & 5 & 6 & 7 & 8 & 9 & 10 & 11 \\
\hline $0-1$ & 71 & 29 & - & - & - & - & - & - & - & - & - & - \\
$1-2$ & 9 & 26 & 26 & 30 & 9 & - & - & - & - & - & - & - \\
$2-3$ & 2 & 4 & 25 & 21 & 23 & 21 & 4 & - & - & - & - & - \\
$3-4$ & 9 & - & 14 & 14 & 27 & 9 & 12 & 3 & 3 & 3 & 6 & - \\
$4-5$ & - & 6 & 13 & 25 & 18 & 13 & - & 6 & 6 & - & - & 13 \\
$5-6$ & - & - & - & - & - & 57 & 29 & - & - & - & - & 14 \\
$6-7$ & - & - & - & - & - & - & 100 & - & - & - & - \\
-
\end{tabular}


Table 11. Details of infection of Salvelinus namaycush, with metazoan parasites, from $\overline{N a i n}$ and Grand Lake.

Species

\begin{tabular}{llllll} 
Nain & & \multicolumn{3}{c}{ Grand Lake } \\
\hline$a^{a} b^{b}$ & $c^{c}$ & $a$ & $b$ & $c$
\end{tabular}

*Discocotyle sagittata (Leuckart, 1842)

*Bunodera luciopercae (Müller, 1776)

Crepidostomum farionis (Müller, 1784)

*Diplostomum spathaceum (Rud., 1819)

*Brachyphallus crenatus (Rud., 1802)

Eubothrium salvelini (Schrank, 1790)

Eubothrium crassum (Bloch, 1779)

Eubothrium sp.

*Proteocephalus tumidocollus Wagner, 1953

Proteocephalus sp. (Type I)

Proteocephalus sp. (Type II)

*Capillaria salvelini Polyanski, 1952

*Contracaecum aduncum (Rud., 1802)

Metabronema salvelini (Fujita, 1922)

Philonema agubernaculum

Simon and Simon, 1936

Nematoda immature

*Acanthocephalus lateralis (Leidy, 1851 )

\begin{tabular}{|c|c|c|c|c|c|}
\hline- & - & - & 15 & 1 & 1.0 \\
\hline 27 & $20-114$ & 52 & 20 & $1-3$ & 1.5 \\
\hline 55 & $1-135$ & 32.7 & 30 & $1-20$ & 6.6 \\
\hline - & - & - & 60 & $1-14$ & 5.6 \\
\hline- & - & - & 80 & $1-56$ & 11.9 \\
\hline 27 & $4-32$ & 13.7 & 5 & 5 & 5.0 \\
\hline - & - & - & 5 & 3 & 3.0 \\
\hline 27 & $6-165$ & 60.3 & 15 & $1-5$ & 2.7 \\
\hline- & - & - & 15 & $1-29$ & 11.3 \\
\hline - & - & - & 15 & $1-8$ & 5.0 \\
\hline 9 & 6 & 6.0 & 70 & $1-67$ & 18.1 \\
\hline 73 & $3-300$ & 95.1 & 45 & $1-15$ & 6.2 \\
\hline- & - & - & 5 & 2 & 2.0 \\
\hline- & - & - & 45 & $1-100$ & 32.0 \\
\hline 9 & 1 & 1.0 & 5 & 2 & 2.0 \\
\hline 18 & 4 & 4.0 & 15 & $1-7$ & 3.0 \\
\hline & - & - & 40 & $1-5$ & 2.5 \\
\hline
\end{tabular}

$a^{a}$ - percentage; $b^{b}$ - range numbers per infected fish;

$c^{c}$ - average number per infected fish.

* new host record. 
20-114: 1-14, respectively). To date, B. 1uciopercae has not been recorded from Salvelinus namaycush, this report constituting a new host record.

\section{Diplostomum spathaceum recovered from s. namaycush}

from coastal Labrador, enlarges the known range of hosts of this species. Bangham (1955) reported the presence of Diplostomulum sp. from this fish in Lake Huron.

The presence of Brachyphallus crenatus in a large number of $\underline{\text { S. namaycush }}$ (52\% infected) from Labrador, provides an opportunity to speculate on the ecology of the fish and parasite. Bykhovsky et al. (1962) considers B. crenatus to be characteristic of marine and migratory fishes and to have been introduced to freshwater primarily by salmonids. Hoffman (1967) reports this parasite from freshwater and marine fishes, undoubtedly a similar situation to that described by the Russian author, as the hosts are primarily salmonids. Entry into freshwater may be brought about as above or by movements of the intermediate host into freshwater or estuaries. Mackay (1963) described $\underline{\mathbf{s}}$. namaycush as the least disposed of all the salmonid fishes to enter salt water. However, the presence of this parasite may suggest limited forays by the fish into an estuarine or marine environment. 
Proteocephalus tumidocollus and the two types of larval Proteocephalus were recovered from this host. Type I was only found in fish taken from Grand Lake (15\% infected), whereas Type II was recovered from fish caught at Nain (90\% infected) and Grand Lake ( $70 \%$ infected). Previous records of proteocephalids infecting $\underline{s}$. namaycush include $\underline{P}$. parallacticus, $\underline{P}$. pusillus (vide Hoffman, 1967) and P. Salvelini (Wardle and McLeod, 1952).

Contracaecum aduncum (Rud., 1802), reported in several species of salmonids in the U.S.S.R. (vide Bykhovsky et al., 1962), had not been found in $\underline{s}$. namaycush from North America prior to the present study.

The only acanthocephalan detected in this host was Acanthocephalus lateralis, which is common in salmonids and coregonids from insular Newfoundland (Sandeman and Pippy, 1967; Threlfall and Hanek, 1970). Its presence in S. namaycush expands the range of known hosts.

No differences were detected between incidence of parasitism and sexes of $\underline{S}$. namaycush. A significant difference $\left(P^{\prime}<.005\right)$ existed for the presence of $\underline{B}$. Crenatus in this species from Nain and Grand Lake $(0 \%$ infected and $80 \%$ infected, respectively), further illustrating the landlocked nature of Trouser Lake (Nain) and the ready 
accessibility of Grand Lake to the estuarine and marine environment.

An increased number of parasite species was noted with increased age of the fish host (Table 12). In addition to an increase in parasite burden, there is also a suggestion that as the fish ages, a point is reached where the parasite burden begins to diminish. Dogiel (1958) cites various authors, notably Bykhovsky (1936), BykhovskayaPavlovskaya (1940), Rakova (1954), Kazadaev (1954) and Layman (1955) who have noted this phenomenon in a variety of fish species.

Salvelinus alpinus (Linnaeus), Arctic char, sea trout, Hudson Bay salmon, ekaluk (eqaluk).

Sixteen genera of metazoan parasites ( 6 of Digenea, 3 of Cestoda, 5 of Nematoda; 1 of Acanthocephala, 1 of parasitic Copepoda) were recovered from salvelinus alpinus from two locations in Labrador. Details of infection with metazoan parasites may be seen in Table 13 .

\section{Bunodera luciopercae, Diplostomum spathaceum,}

Derogenes varicus and Phyllodistomum limnosa Sandeman and Pippy, 1967 were recovered from $3 \%, 6 \%, 3 \%$ and $3 \%$, respectively from fish from either Nain or Grand Lake. Found only in 
Table 12. Relationship between the number of parasite species and age of Salvelinus namaycush

(Figures in the body of the table show the percentage of fish in each age class).

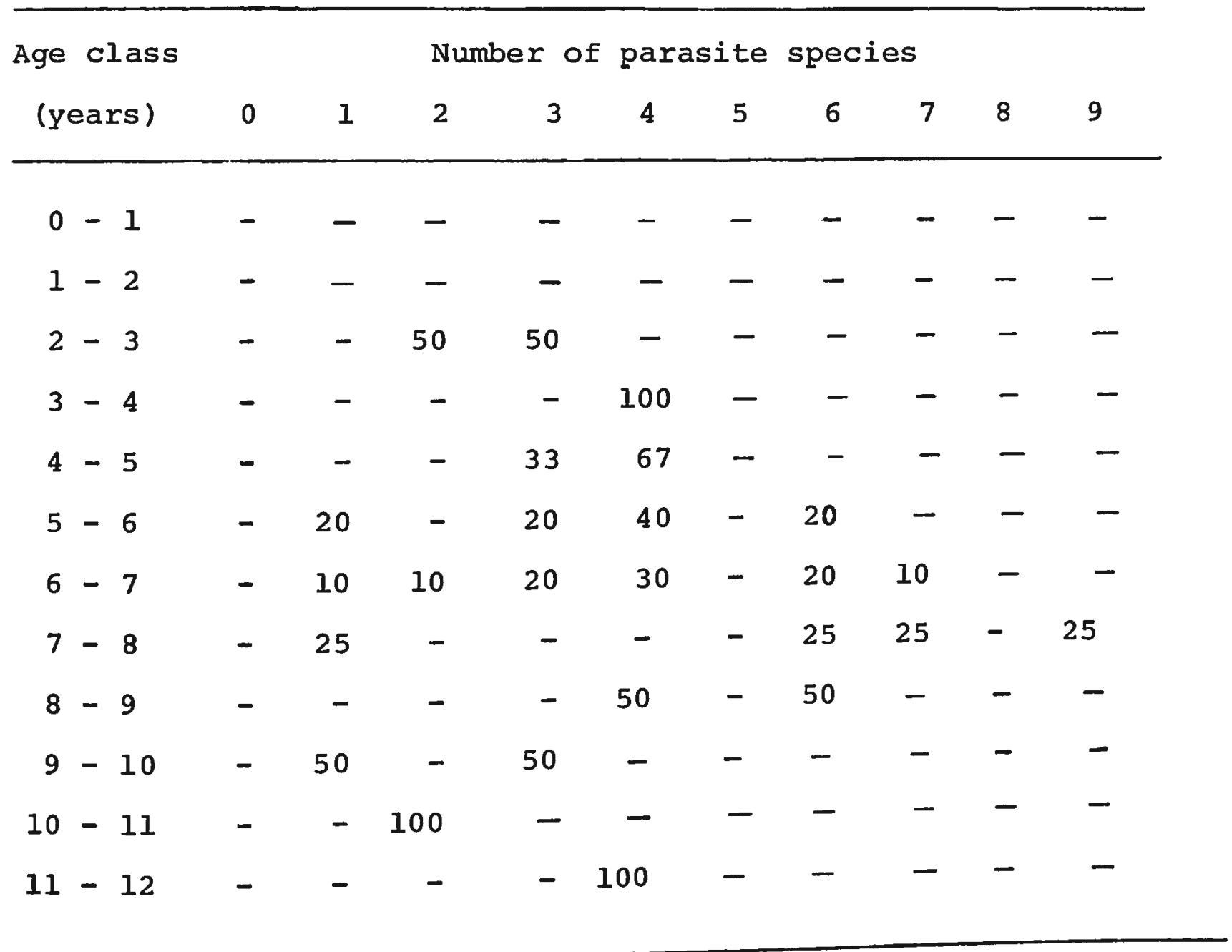


Table 13. Details of infection of Salvelinus alpinus, with metazoan parasites, from Nain and Grand Lake.

\begin{tabular}{|c|c|c|c|c|c|c|}
\hline \multirow{2}{*}{ Species } & \multicolumn{3}{|c|}{ Nain } & \multicolumn{3}{|c|}{ Grand Lake } \\
\hline & $a^{a}$ & $b^{b}$ & $c^{c}$ & $a$ & $b$ & C \\
\hline * Bunodera $\frac{\text { luciopercae }}{(\text { Müller }}$ & 4 & 1 & 1.0 & - & - & - \\
\hline$\frac{\text { Crepidostomum farionis }}{\text { (Mưller, 178 }}$ & 17 & $1-2$ & 1.2 & - & - & - \\
\hline$\frac{\text { Diplostomum spathaceum }}{(\text { Rud., } 1819)}$ & - & - & - & 33 & 2 & 2.0 \\
\hline${ }^{*}$ Phyllodistomum $\frac{\text { limnosa }}{\text { Sandeman and }} \frac{1967}{\text { Pippy, } 1967}$ & 4 & 5 & 5.0 & - & - & - \\
\hline${ }^{\star D e r o g e n e s}$ (Müller, $\frac{\text { varicus }}{1784)}$ & 4 & 1 & 1.0 & - & - & - \\
\hline${ }^{* \text { Brachyphallus }} \frac{\text { crenatus }}{\text { (Rud., 1802) }}$ & 21 & $7-56$ & $21 \cdot 5$ & 83 & 1 & 1 \\
\hline$\frac{\text { Bothrimonus }}{\text { Duvernoy, }} \frac{\text { sturionis }}{1842}$ & 48 & $2-45$ & 11.7 & - & - & - \\
\hline$\frac{\text { Eubothrium }}{\text { (Schrank, }} \frac{\text { salvelini }}{1790)}$ & 10 & $1-6$ & 2.6 & - & - & - \\
\hline$\frac{\text { Eubothrium }}{\text { (Bloch, }} 1 \frac{\text { crassum }}{779)}$ & 14 & $1-25$ & 10.0 & - & - & - \\
\hline Eubothrium sp. & 10 & $2-5$ & 3.0 & 100 & $100-343$ & 171.8 \\
\hline * $\frac{\text { Proteocephalus }}{\text { Wagner, }} \frac{\text { tumidocollus }}{1953}$ & 17 & $3-12$ & 8.8 & - & - & - \\
\hline Proteocephalus sp. (Type I) & 4 & 1 & 1.0 & - & - & - \\
\hline Proteocephalus sp. (Type II) & 35 & $1-24$ & 8.9 & - & - & - \\
\hline *Capillaria salvelini & 4 & 10 & 10.0 & - & - & - \\
\hline$\frac{\text { Contracaecum aduncum }}{(\text { Rud. } 1802)}$ & 4 & 1 & 1.0 & - & - & - \\
\hline Contracaecum sp. & 4 & 5 & 5.0 & - & - & - \\
\hline *Anisakis sp. & 10 & 1 & 1.0 & - & - & - \\
\hline 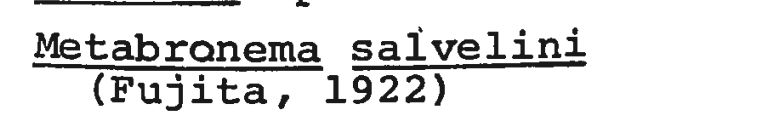 & 4 & 1 & 1.0 & - & - & - \\
\hline Nematoda immature & 4 & 4 & 4.0 & - & - & - \\
\hline * $\frac{\text { Philonema a }}{\text { subernaculum }}$ & 24 & $1-5$ & 2.1 & - & - & - \\
\hline
\end{tabular}


Table 13. Details of infection of Salvelinus alpinus, with metazoan parasites, from Nain and Grand Lake (contd.).

\begin{tabular}{|c|c|c|c|c|c|c|}
\hline \multirow{2}{*}{ Species } & \multicolumn{3}{|c|}{ Nain } & \multicolumn{3}{|c|}{ Grand Lake } \\
\hline & $a^{a}$ & $b^{b}$ & $c^{c}$ & $\mathbf{a}$ & $\mathbf{b}$ & C \\
\hline${ }^{\star} \frac{\text { Acanthocephalus }}{(\text { Leidy, }} \frac{\text { lateralis }}{1851)}$ & 31 & $1-2$ & 1.4 & - & - & - \\
\hline$\frac{\text { Salmincola edwardsii }}{\text { (Olsson, }}$ & 14 & $1-15$ & 4.8 & - & - & - \\
\hline
\end{tabular}

$a^{a}$ - percentage; $b^{b}$ - range numbers per infected fish;

$c^{c}$ - average number per infected fish.

* new host record. 
small numbers, they do, however, constitute new host records for this salmonid, with the exception of $D$. spathaceum.

A trematode found in marine and anadromous fishes from the U.S.S.R. (vide Bykhovsky et al., 1962), North America (yide Hoffman, 1967) and common in salmonids from Labrador, Brachyphallus crenatus was recovered from S. alpinus ( 318 infected) from Labrador. Ranges and mean number per infected host differ considerably within each sampling area (Nain, range 7 - 56, mean 22; Grand Lake, l/infected host) and probably reflect differences in the fishes' environments. The majority of fish from Nain infected with this trematode were caught in estuarine (Nain Rarbour) or marine (Unity Bay) waters, whereas the Grand Lake fish were captured in freshwater.

Bothrimonus sturionis Duvernoy, 1842, a tapeworm of numerous marine and anadromous teleosts (Burt and sandeman,

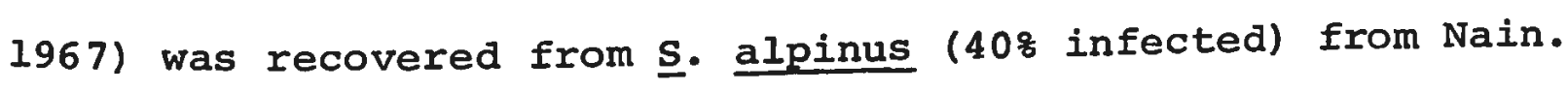
Burt and Sandeman in their paper, reviewed the systematic position of Bothrimonus Duvernoy, 1842, Diplocotyle Krabbe, 1874 and Didymobothrium Nybelin, 1922, and concluded that all the material examined was $\underline{B}$. sturionis. The presence of this tapeworm in $\underline{s}$. alpinus from eastern Labrador expands the known geographical range of this parasite. 
To date, only Proteocephalus exiguus La Rue, 1911

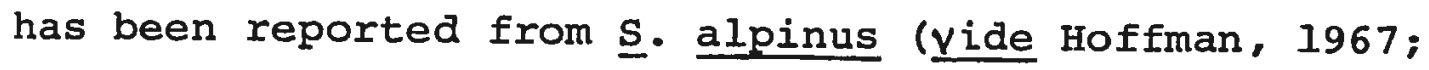
vide Bykhovsky et al., 1962). The presence of $\underline{P}$. tumidocollus in this fish constitutes a new host record and increases the number of Labrador hosts for this tapeworm. $\underline{p}$. exiguus differs from $\underline{P}$. tumidocollus in its smaller sucker size $(0.058-0.085 \mathrm{~mm})$ and scolex covered by a dense network of small spines (vide Freze, 1965).

Anisakis sp. (larvae), Capillaria salvelini Polyanski, 1952 and Philonema agubernaculum Simon and Simon, 1936 were recovered from $\underline{s}$. alpinus for the first time. Whereas the former two were recovered from only a few fish,

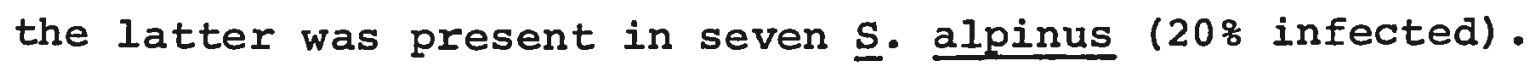
Members of the Family, Philometridae often have pathological disorders associated with them, particularly philonema spp. (Margolis, 1970). However, no evidence of such conditions were noted in Labrador fish examined.

No differences existed between the sexes in parasite incidence in $\underline{\mathbf{s}}$. alpinus.

A correlation between the number of species of parasites found in a fish and the age was noted (Table 14), a situation quite common throughout the Labrador salmonids. 
$-47-$

Table 14. Relationship between the number of parasite species and age of Salvelinus alpinus (Figures in the body of the table show the percentage of fish in each age class).

Age class

(years)

$0-1$

$1-2$

$2-3$

$3-4$

$4-5$

$5-6$

$6-7$

$7-8$
Number of parasite species

1

2

3

4

5

0

$-$

$-\quad 100$

$-$

27

27

33

33

50

50

50

- $\quad-$

-
-

-

-
-

40 $-\quad 50$
$-\quad 5$
18

-

-
$-$

$-$

$-$

50

60

50
9

33

-

-

$-$

- 
Coregonus clupeaformis (Mitchill), Lake whitefish, common whitefish, whitefish.

Eleven genera of metazoan parasites ( 1 of Monogenea, 3 of Digenea, 2 of Cestoda, 3 of Nematoda, I of Acanthocephala, 1 of parasitic Copepoda) were recovered from $\underline{c}$. clupeaformis from Grand Lake. Details of infection with these metazoan parasites may be seen in Table 15.

Bykhovsky et al. (1962) and skrjabin (1960) noted the occurrence of metacercariae of Diplostomum spathaceum in coregonid species from the U.S.S.R., while Bangham (1955) recorded Diplostomulum sp. from coregonids of the Lake Huron region. Sandeman and Pippy (1967) and Threlfall and Hanek (1970) made no mention of Diplostomulum spp. in studies of salmonids and coregonids from insular Newfoundland and the Avalon Peninsula, respectively. The presence of this larval trematode in the eye humours of $c$. clupeaformis (67\% infected) constitutes a new host record for North America.

Coregonid species in the U.S.S.R. have been reported to be infected with several species of Phyllodistomum (vide Bykhovsky et al., 1962). The sole North American record of a gorgoderia species in a coregonid is that of Dechtiar (1966), who described $\underline{P}$. coregoni from $\underline{C}$. clupeaformis 
Table 15. Details of infection of Coregonus clupeaformis, with metazoan parasites, from Grand Lake.d

\begin{tabular}{|c|c|c|c|}
\hline \multirow{2}{*}{ Species } & \multicolumn{3}{|c|}{ Grand Iake } \\
\hline & $a^{a}$ & $b^{b}$ & $c^{c}$ \\
\hline$\frac{\text { Discocotyle }}{\text { (Leuckart }} \frac{\text { sagittata }}{1842)}$ & 7 & $1-3$ & 2.0 \\
\hline$\frac{\text { *Crepidostomum }}{\text { (Müller, } 1784 \text { ) }}$ & 3 & 1 & 1.0 \\
\hline$\frac{\text { *Diplostomum spathaceum }}{\text { (Rud., } 1819)}$ & 67 & $2-98$ & 19.4 \\
\hline * $\frac{\text { Phyllodistomum }}{\text { Sandeman and }} \frac{\text { Pimnosa }}{\text { Pippy, } 1967}$ & 3 & 1 & 1.0 \\
\hline Eubothrium sp. & 7 & $3-4$ & 3.5 \\
\hline$\frac{\text { *Proteocephalus }}{\text { wagner, } 1953}$ & 7 & $3-17$ & 10.0 \\
\hline Proteocephalus sp. (Type I) & 13 & $4-17$ & 8.8 \\
\hline Proteocephalus sp. (Type II) & 40 & $1-20$ & 7.3 \\
\hline$\frac{{ }^{*} \text { Capillaria }}{\text { Polyanski }} \frac{\text { salvelini }}{1952}$ & 3 & 1 & 1.0 \\
\hline$\frac{\text { *Metabronema }}{\text { (Fujita, }}$ salvelini & 3 & 7 & 7.0 \\
\hline$\frac{\text { *Philonema agubernaculum }}{\text { Simon and Simon, } 1936}$ & 3 & $I$ & 1.0 \\
\hline$\frac{\text { Acanthocephalus }}{(\text { Leidy, I85I) }}$ & 3 & 1 & 1.0 \\
\hline *Salmincola $\frac{\text { extensus }}{(\text { Kessler }}$ & 13 & $1-3$ & 1.5 \\
\hline
\end{tabular}

$a^{a}$ - percentage; $b^{b}$ - range numbers per infected fish;

$c^{c}$ - average number per infected fish.

d - includes three $C$. clupeaformis from Naskaupi River.

* new host record. 
caught in western ontario. In a $\underline{c}$. clupeaformis from Naskaupi River (a major tributary of Grand Lake, $53^{\circ} 35^{\prime} \mathrm{N}$, $\left.60^{\circ} 54^{(} \mathrm{W}\right)$, a single specimen of Phyllodistomum limnosa was recovered. This report constitutes a new host record.

Common among coregonid species because of their mode of feeding, Proteocephalus spp. have been reported from these fishes, both in North America (yide Hoffman, 1967) and in the U.S.S.R. (vide Bykhovsky et a1., 1962). The presence of $\underline{P}$. tumidocollus in $C$. clupeaformis ( $7 q$ infected) expands the range of known hosts. Proteocephalus sp. (Type I) was present in only a relatively small number of C. clupeaformis (13\% infected), contrasting sharply with that of Proteocephalus sp. (Type II) ( $40 \%$ infected).

Acanthocephalus lateralis, recovered in large numbers from C. clupeaformis examined from insular Newfoundland (1008 infected - Sandeman and Pippy, 1967) and the Avalon Peninsula (1008 infected - Threlfall and Hanek, 1970), was conspicuous by its virtual absence ( 38 infected) in this Labrador coregonid.

Kabata (1969) in a major revision of the Genus Salmincola synonymized Achtheres extensus (Kessler, 1868) Markevich, 1937, common on coregonid species from the U.S.S.R. (Vide Bykhovsky et al., 1962), Lernaeopoda coregoni Smith, 1874, 
on Coregonus albus from Michigan (vide Kabata, 1969) and s. wisconsiniensis Tidd and Bangham, 1945, on Leucichthys artedi clemensi from Wisconsin, with Salmincola extensus. The presence of this parasitic copepod constitutes a new host record and extends the geographical range of this species in North America.

No differences were detected between incidence of parasitism and sex of $\underline{c}$. clupeaformis.

No correlation between age of $\mathrm{fish}$ and the parasite burden was evident. A close similarity in diet between young and old fish may account for this observation. Whereas many species of salmonids undergo a change in diet, often becoming piscivorous with an increase in age (Leim and scott, 1966; Scott and Crossman, 1963), many coregonids including c. clupeaformis observe a fairly constant diet throughout their life span (Hart, 1931; Chen , M.Sc., 1967).

Prosopium cylinaraceum (Pallas), Round whitefish, bottlefish.

Prosopium cylindraceum, the only other species of coregonid occurring in Labrador (Backus, 1957) was found to be infected with eleven genera of metazoan parasites (2 of Monogenea, 2 of Digenea, 2 of Cestoda, 2 of Nematoda, 1 of Acanthocephala, 2 of parasitic Copepoda). Details of infection of this host with metazoan parasites may be seen in Table 16 . 
Table 16. Details of infection of Prosopium cylindraceum, with metazoan parasites, from Grand Lake.

\begin{tabular}{|c|c|c|c|}
\hline \multirow{2}{*}{ Species } & \multicolumn{3}{|c|}{ Grand Irake } \\
\hline & $a^{a}$ & $b^{b}$ & $c^{c}$ \\
\hline$\frac{\text { Tetraonchus }}{\text { Mizelle and Webb, } 1953}$ & 27 & $2-10$ & 4.9 \\
\hline$\frac{\text { Discocotyle }}{\text { (Ieuckart }}, \frac{\text { sagittata }}{1842)}$ & 3 & 2 & 2.0 \\
\hline * Bunodera $\frac{\text { luciopercae }}{(\text { Müller }}$ & 3 & 5 & 5.0 \\
\hline$\frac{{ }^{*} \text { Diplostomum spathace um }}{\text { (Rud., 1819) }}$ & 53 & $2-53$ & 11.0 \\
\hline$\frac{* \text { Eubothrium salvelini }}{\text { (Schrank, }}$ & 3 & 1 & 1.0 \\
\hline Eubothrium sp. & 3 & 2 & 2.0 \\
\hline Proteocephalus sp. (Type II) & 3 & 1 & 1.0 \\
\hline *Capillaria salvelini & 7 & $1-2$ & 1.5 \\
\hline$\frac{{ }^{*} \text { Philonema }}{\text { Simon agubernaculum }}$ & 10 & $1-3$ & 1.7 \\
\hline Nematoda immature & 17 & $1-9$ & 3.4 \\
\hline$\frac{{ }^{*} \text { Acanthocephalus }}{(\text { Ieidy, 1851) }}$ & 10 & $1-6$ & 3.0 \\
\hline *Ergasilus $\frac{\text { luciopercarum }}{\text { Henderson, } 1926}$ & 7 & $1-10$ & 5.5 \\
\hline$\frac{\text { *Salmincola }}{(\text { Kessler }}, \frac{\text { thymalli }}{1868)}$ & 27 & $I-2$ & 1.3 \\
\hline
\end{tabular}

$a^{a}$ - percentage; $b^{b}$ - range numbers per infected fish; $c^{c}$ - average number per infected fish.

* new host record. 
Mizelle and Webb (1953) described Tetraonchus variabilis from gills of the Mountain whitefish prosopium williamsoni (Girard) from Wyoming and $\underline{p}$. cylindraceum from Alaska. Neither Bykhovsky et al. (1962), nor Hoffman (1967) make further reference to this species on coregonids from the U.S.S.R. or North America. Eight P. cylindraceum (27\%) from Grand Lake were found to be infected with this monogenean (Figure 4). A comparison of morphological characteristics of the Labrador specimens with those of Mizelle and Webb (1953) may be seen in Table 17. The Labrador specimens differ from the description of the previous authors in the following ways: (1) slightly smaller size, (2) variable length of the connecting bar and (3) greater length of the ventral median hook. The latter difference may be due to lack of standardization of measuring techniques. The measurement procedure used in the present study was that of Bykhovsky et al. (1962), whereas that of Mizelle and Webb (1953) was unclear. The latter authors described the ventral bar (connecting bar) as highly variable ranging from a well developed structure through a vestigial condition to complete absence in occasional specimens. The vestigial condition is more the rule than the exception in the Labrador specimens (Figure $4 \mathrm{C}$ ), only a few specimens lacking it entirely. Closely related species include $\underline{T}$. alaskensis described by Price (1937) from the Alaskan cutthroat trout Salmo mykiss, which differs from the 
Figure 4. Haptoral armament and copulatory complex of Tetraonchus variabilis Mizelle and Webb (1953) from Prosopium cylindraceum from coastal Labrador.

(a) ventral median hook,

(b) dorsal median hook,

(c) variation in size of connecting bars,

(d) marginal hooks,

$(e, f)$ variation in size and shape of copulatory organ (co-copulative organ, sbc - supporting bar of copulative organ). 

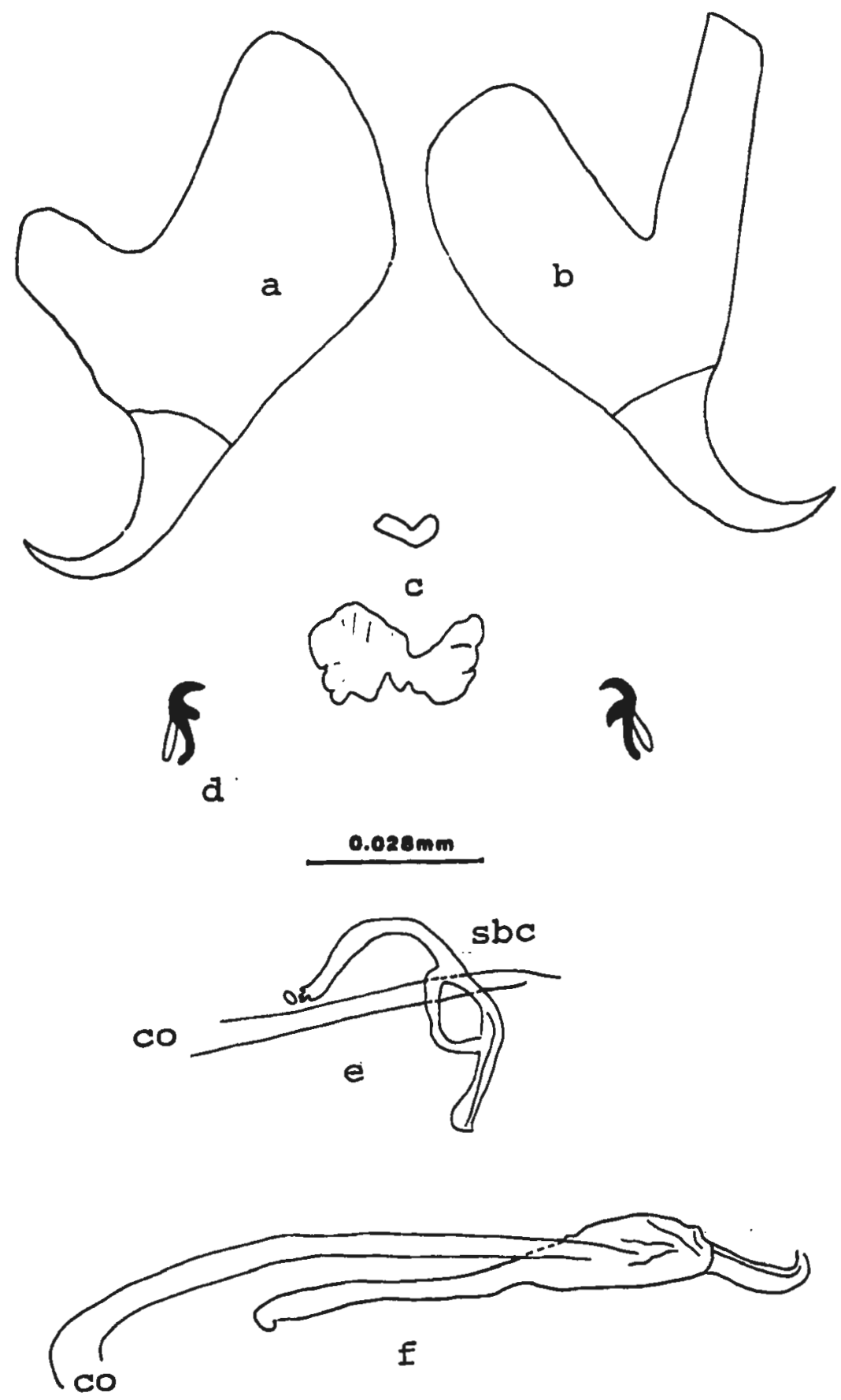
Table 17. Measurements (microns) of Tetraonchus variabilis recovered from Labrador, and a comparison with the original description of Mizelle and Webb, 1953.

\begin{tabular}{lcccc}
\hline \multirow{2}{*}{ Morphological criteria } & \multicolumn{2}{c}{$\begin{array}{c}\text { Labrador } \\
\text { specimens })\end{array}$} & $\begin{array}{c}\text { Mizelle and } \\
\text { Webb, }\end{array}$ & (3353 \\
\cline { 2 - 5 } & Average & Range & Average & Range \\
\hline & & & & \\
Length & 1184 & $775-2520$ & 1558 & $1080-2250$ \\
*Width & 173 & $80-450$ & 334 & $126-558$ \\
Marginal hooks - length & 14 & $12-18$ & - & - \\
Dorsal median hooks - length & 83 & $62-99$ & 94 & $76-105$ \\
Dorsal median hooks - width & 65 & $46-80$ & 69 & $59-80$ \\
Ventral median hooks - length & 66 & $55-75$ & 101 & $76-135$ \\
Ventral median hooks - width & 62 & $47-85$ & 74 & $63-80$ \\
Cirrus - length & 54 & $49-89$ & 59 & $41-63$ \\
Support bar - length & 54 & $32-79$ & 49 & $36-58$ \\
** Connecting bar - length & 14 & $10-28$ & 30 & $16-63$ \\
Haptor - length & 130 & $90-180$ & 154 & $105-211$ \\
Haptor - width & 247 & $180-387$ & 206 & $139-258$ \\
\end{tabular}

* Labrador width - at cirrus; Mizelle and Webb, 1953 - greatest width.

** 11 specimens lacked this structure. 
present specimen in possessing larger median hooks (Dorsal $0.110 \times 0.075 \mathrm{~mm}$; Ventral $0.107 \times 0.075 \mathrm{~mm})$, cirrus (0.080 mm) and supporting bar $(0.060-0.065 \mathrm{~mm})$. The cirrus is strongly curved proximally, a feature not evident in the Labrador specimens (Figure 4f). The connecting bar is lobed and measures $0.030-0.035 \times 0.020-0.025 \mathrm{~mm}$. The presence of T. variabilis in Labrador, constitutes a new geographical record.

Metacercariae of Diplostomum spathaceum, common in coregonid species in the U.S.S.R. (vide Bykhovsky et al., 1962), have not, to date, been recovered from Prosopium cylindraceum (vide Hoffman, 1967). Hoffman (1967) did note, however, the presence of a Diplostomulum sp. in this fish host. As in C. Clupeaformis, D. spathaceum was found to infect a very high percentage of $\underline{P}$. Cylindraceum (53\%).

\section{Eubothrium salvelini, Eubothrium sp. and}

Proteocephalus sp. (Type II) have never, previously, been recorded from this host.

Ergasilus luciopercarum Henderson, 1926, a parasitic Copepod, has been recorded from Salvelinus namaycush and Coregonus spp. (Bere, 1931), although Roberts (1970) considers this improbable. Sandeman and Pippy (1967) recovered this species on $\underline{s}$. fontinalis from Raft Pond, on the Great Northern Peninsula, Newfoundland. Davis (1969) found large 
numbers of males of this species in a plankton sample taken in Barachois Pond, Barachois Pond Provincial Park, near Stephenville: Newfoundland. Immature Ergasilus sp. were recovered from $\underline{\text { S. }}$ fontinalis and salmo trutta from the Avalon Peninsula by Threlfall and Hanek (1970). Copepods (Figure 5) identified as Ergasilus luciopercarum were recovered from two $\underline{P}$. cylindraceum ( 78 infected) from Grand Lake. This report constitutes a new host record and greatly expands the range of this parasitic copepod.

Salmincola thymalli which is circumpolar in distribution, has been recorded from salmonid, thymallid and coregonid species (Kabata, 1969). Prosopium sp. from Keewatin, Nueltin Lake and Alaska were found to be infected with this parasitic copepod (vide Kabata, 1969). The presence

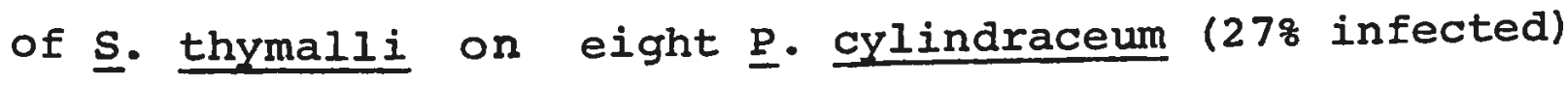
from Grand Lake, constitutes a new geographical record. In his revision of the genus Salmincola, Kabata (1969) synonymizes Achtheres coregoni with $\underline{S}$. coregonorum (Kessler, 1868). A. coregoni had previously been recovered

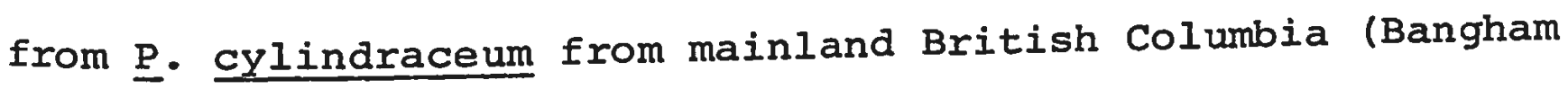
and Adams, 1954) and is a common parasite of Coregonus cylindraceus in the U.S.S.R. (vide Bykhovsky et al., 1962). Kabata (1969) suggested that because of morphological similarities, particularly the shape and armament of the 
Figure 5. Ergasilus luciopercarum Henderson, 1926 , from Prosopium cylindraceum from coastal Labrador.
(a) antenna I, (b) antenna II,
(c) furca, (d) swimming legs, first pair,
(e) swimming legs, second pair,
(f) swimming legs third pair,
(g) swimming legs, fourth pair. 


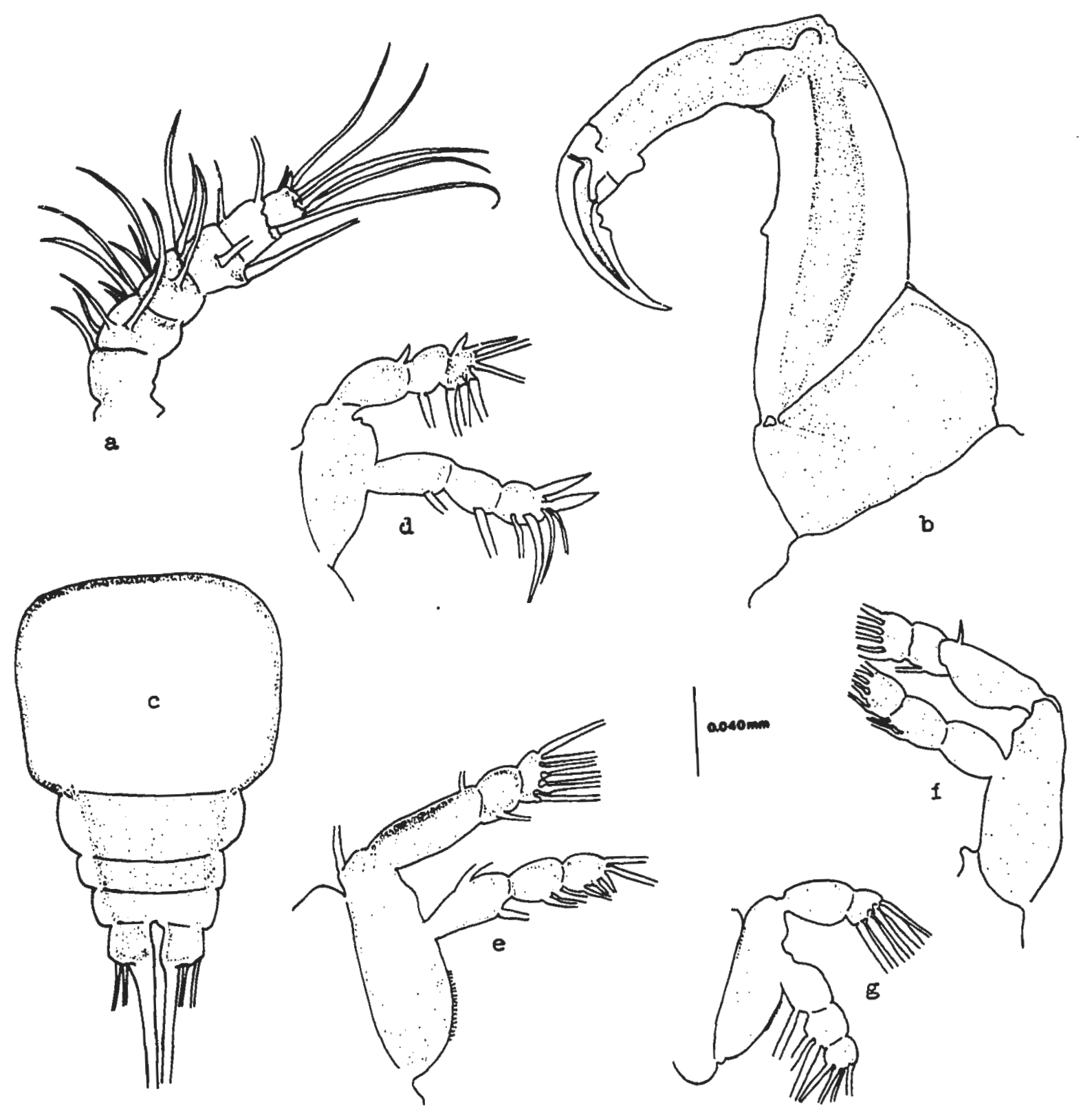


maxillipeds, $\underline{\mathrm{s}}$. coregonorum may have evolved from $\underline{\mathrm{s}}$. thymalli, the more common and widely distributed of the two.

No differences were noted between incidence of parasitism and sex of $\underline{P}$. cylindraceum.

No correlation between parasite burden and age of $\underline{P}$. cylindraceum was evident which as in the case of Coregonus clupeaformis, may be attributed to diet and mode of feeding. 
General Discussion

Tetraonchus variabilis, a monogenetic trematode, was recovered from $\underline{P}$. cylindraceum (27\% infected) and S. fontinalis ( 18 infected). A significant difference $(\mathrm{P}<.005)$ exists between the incidence of this parasite in salmonids and coregonids.

Bunodera Iuciopercae was one of the most frequently encountered parasites of Labrador salmonids, particularly S. fontinalis ( $51 \%$ infected). The normal definitive hosts of this helminth are Perca flavescens, and Micropterus salmoides in North America (Linton, 1940; vide Hoffman, 1967) and similar predatory fish in the U.S.S.R. (vide Bykhovsky et al., 1962). Threlfall and Hanek (1970) recovered B. Iuciopercae from the northern pike, Esox lucius L. from Eagle River. Its presence in salmonid species is unusual, although Sandeman and Pippy, 1967 reported B. 1uciopercae from $\underline{s}$. fontinalis for the first time. When salmonids and coregonids were compared using a $(2 \times 2)$ contingency classification, a distinct predilection was noted for the former $(P<.005)$.

Crepidostomum farionis was prevalent in all salmonid species examined (Table 2). Differences in the number of each fish species infected were significant $(P<.005)$. 
The difference between the high incidence in salmonids and the low incidence in coregonids was also significant $(P<.005)$. Sandeman and Pippy (1967) showed that this parasite has a wide distribution and is common in salmonid species from insular Newfoundland (‥ fontinalis, 62.68 infected; $\underline{\text { s. salar, }}$ parr 52.68, smolt 100\%, landlocked $45.2 \%$ infected; S. trutta 88 infected; $\underline{\text { S. gairdneri }} 74.78$ infected). In contrast to this previous investigation, Threlfall and Hanek (1970) found C. farionis in a much lower percentage of fish (‥ fontinalis 198; S. trutta $4.5 \%$ ) than was noted in salmonid species from Labrador during the present work. Pippy (MS., 1969), in a comprehensive study of the potential of parasites for use as biological tags, found a very high degree of infection with C. farionis among salmonids from insular Newfoundland and variable results for Labrador. s. salar (smolts) from the English and Eagle Rivers, showed $0 \%$ and 678 infection respectively with this helminth. Time of sampling, age of the fish, availability of the correct intermediate host(s) and location may contribute to the variations in infection noted to date.

Metacercariae of Diplostomum spathaceum were common in both salmonid and coregonid species from Labrador. Amongst salmonids there was no significant difference in the numbers of each species infected (Table 2). Contrasting markedly 
with the relatively low frequency of this helminth in the salmonid species is the extremely high frequency noted in the coregonid species (Table 2). The difference in the degree of infection between the salmonid and coregonid species was significant $(P<.005)$ (218 of salmonids infected; 608 of coregonids infected). Pippy (MS., 1969) noted that $\underline{\text { s. salar }}$ (smolts) from Eagle River, as well as from insular Newfoundland with only a few exceptions, exhibited heavy infections with Diplostomulum sp., whereas this species was not recorded by either Sandeman and Pippy (1967) or Threlfall and Hanek (1970). Bangham and Adams (1954) recovered Diplostomulum sp. from several salmonid and coregonid species, including $\underline{\text { s. fontinalis }}$ (4.5\% infected) and $\underline{P}$. cylindraceum (88.8\% infected) from British Columbia. skrjabin (1960) listed the species of salmonids and coregonids that serve as hosts for metacercariae of D. spathaceum. Threlfall (1968 a, b) recorded adults of this trematode infecting marine birds of the eastern coast of Canada. Hoffman (1960) in a synopsis of the Strigeiodea separates the various larval groups on the basis of origin and type of cyst and morphological characteristics, no true cyst of parasitic origin being formed by members of the larval group Diplostomulum.

Derogenes varicus was recovered from few $\underline{S}$. salar

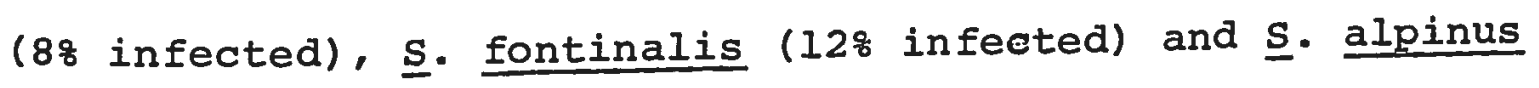
(3q infected). S. namaycush was uninfected. The presence 
of this predominantly marine trematode appears to be associated with movements of the fish in estuaries and in

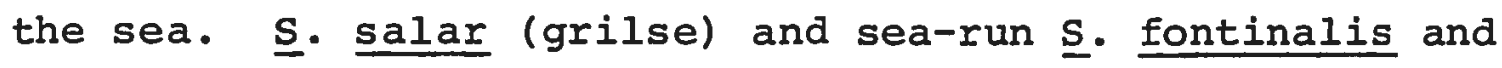
S. alpinus were found to be infected, whereas the species of salmonids and coregonids inhabiting only freshwater, were not. Linton (1940) reported that this parasite has been recorded from a large number of hosts, but only in small numbers. This seems to be supported by results obtained during the present study (maximum intensity of infection 41 , mean 12). D. varicus was found to infect $\underline{\text { s. salar (grilse) }}$ (29\%) from insular Newfoundland (Sandeman and Pippy, 1967) and to be widespread and abundant in this fish in waters along the eastern coast of Canada, Greenland and Great Britain (Pippy, MS., 1969).

\section{Brachyphallus crenatus exhibited an unusual} distribution in the species of salmonids of coastal Labrador. Few S. salar (grilse, 3\%) were infected with this trematode. The number of $\underline{\mathrm{s}}$. fontinalis parasitized was only slightly higher ( $12 \%$ infected), but this helminth was found much more

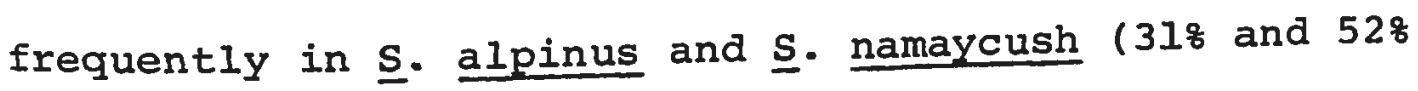
infected, respectively). The distribution of $\underline{B}$. crenatus in the salmonid species examined was not homogeneous ( $P<.005$ ). Sandeman and Pippy (1967), Pippy (MS., 1969) and Threlfall and Hanek (1970) showed that $\underline{B}$. crenatus is a common helminth 
of S. salar on the eastern coast of Canada, in contrast to the low percentage incidence noted in Labrador. Its presence in $\mathbf{s}$. namaycush is unusual and suggests that the movements of this host are not as restricted as is indicated in the literature.

Bothrimonus sturionis was recovered from only

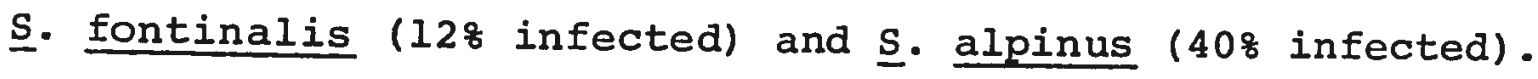
Elsewhere, B. sturionis has been recorded from a variety of teleosts over a considerable geographical range in the Holarctic (Burt and Sandeman, 1969). These authors also include $\underline{s}$. salar from insular Newfoundland, a species of fish found to be uninfected in Labrador in the present study.

Eubothrium salvelini was recovered from $\underline{\text { s. fontinalis }}$ (15\% infected), $\underline{\text { s. namaycush }}$ (13\% infected) and $\underline{\text { s. alpinus }}$

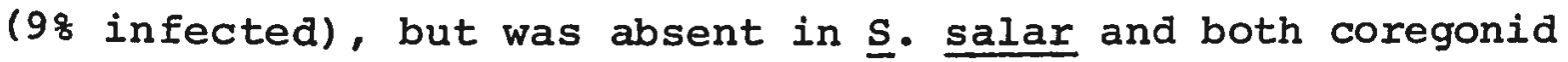
species (Table 2). Absence of this cestode in $\underline{S}$. salar in Labrador tended to support the observation of Vik (1963) of host specificity. In a survey of the occurrence and distribution of E. Crassum and E. Salvelini of Lake Änoya, Norway, he found the latter to infect only Salmo alpinus (Salmo alpinus = Salvelinus alpinus, the Arctic char) and, on one occasion, a whitefish. This host distribution appears to have no validity in other areas, as Sandeman and Pippy (1967) recorded E. Salvelini in a number of hosts including 
S. fontinalis (258 infected); S. salar (parr 10.58, landlocked 698 infected); Salmo trutta ( 48 infected) and Salmo gairdneri (228 infected). Threlfall and Hanek (1970) recovered this helminth from S. salar (grilse, $66 \%$ infected) from witless Bay, on the Avalon Peninsula. This parasite is also well distributed among juvenile $\underline{\text { s. }}$ salar from the eastern coast of Canada and Great Britain (Pippy, MS., 1969).

Eubothrium crassum was seen in s. salar ( 408 infected),

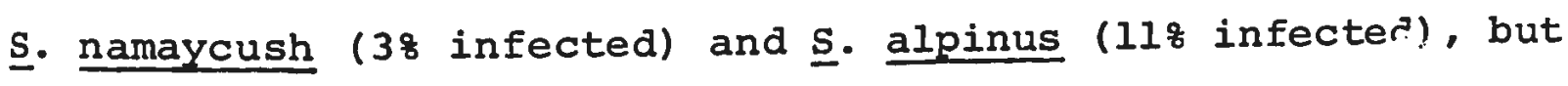

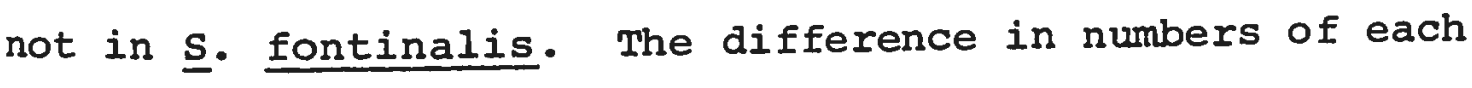
species of fish infected was significant $(P<.005)$. Sandeman and Pippy (1967) reported E. crassum from S. salar (grilse, $64 \%$ infected) from insular Newfoundland. S. salar from the Avalon Peninsula were uninfected (Threlfall and Hanek, 1970). However, a survey conducted by Pippy (MS., 1969) showed that this species is abundant on Canada's eastern coast, in Greenland and in southwest England. In this same area (River Exe, Devon), Kennedy (1969) reported 578 of $\underline{\text { s. Salar }}$ infected with this parasite.

The presence of E. crassum in a wide variety of fishes, predominantly salmonid species, has led to much speculation about the origin of the parasite and indirectly, the fish host. Heitz (1917) considers E. crassum as a "purely potamophilous" form. However, he was unable to 
explain the loss of this cestode as the host, s. salar, migrates upstream. In contrast, Dogiel and Petrushevski (1935, vide Kennedy, 1969) consider it a marine form and Mamaev, Parukhin, Baeva and Oshmarin (1959, yide Kennedy, 1969), an estuarine form. Vik (1963) believes that sea trout ( $\underline{S}$. trutta) became infected by eating migratory G. aculeatus that acquire the parasite in freshwater. Kennedy (1969) suggested that two races of $\underline{E}$. crassum may exist, both a marine and a freshwater one. The existence of such a species complex, may help our understanding of the evolution of the Salmonidae. Jones (1959) suggested that the Salmonidae are of a marine or estuarine origin, while Margolis (1965) used parasitological data in opposing this view. In enumerating parasites that show a predilection for salmonids, the freshwater parasites greatly outnumbered the marine ones. On this basis, Margolis (op. cit.) considered the earlier evolutionary stage to have the larger natural parasite burden, that is, freshwater. Results from the Labrador investigations indicate that a greater variety of marine and estuarine parasites are capable of infecting salmonids than was previously suspected. The presence of these parasites serve only to cloud the above theories.

Immature forms of Eubothrium sp. occurred in all species of fish examined, a slight predilection for salmonids $(P<.05)$ being noted. Threlfall and Hanek (1970) recorded 


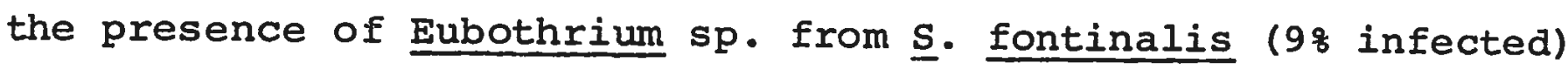
from the Avalon Peninsula. A larger number of this host (19\%) were infected with Eubothrium in Labrador, the degree of infection also being greater than that observed by the latter authors (32.8: 9.7 per infected host, respectively).

\section{Proteocephalus tumidocollus was recovered from}

S. fontinalis ( 48 infected), S. namaycush (10\% infected), S. alpinus ( 148 infected) and c. clupeaformis ( 78 infected),

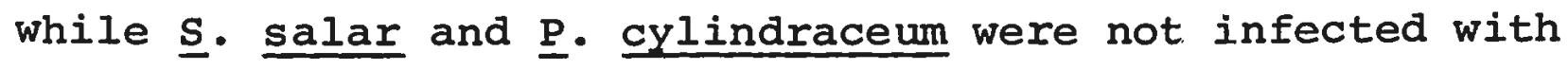
it. Studies conducted by Sandeman and Pippy (1967) in insular Newfoundland, Threlfall and Hanek (1970) on the Avalon Peninsula and Pippy (MS., 1969) along the eastern seaboard of Canada, in Greenland and in Great Britain, did not indicate the presence of this or any other proteocephalid. The only record of this helminth, to date, is that of wagner (1953, 54). Proteocephalus sp. (Type I) was found in the same species of fish that were infected with $\underline{P}$. tumidocollus and in s. salar. The number of fish infected was low (Table 2) and the degree of infection approximated that of the latter parasite. On the other hand, Proteocephalus sp. (Type II) exhibited a greater degree of infection than the other proteocephalids in the fish examined, particularly $\underline{s}$. namaycush. A significant difference $(P<.005)$ was noted in the distribution of this helminth in the species of salmonids 
examined (Table 2). There was, however, no significant difference between the occurrence of this cestode in salmonid and coregonid species.

Capillaria salvelini was noted in both salmonid and coregonid species (Table 2), there being no significant difference in the degree of infection between the two groups. However, it was noted that the distribution within the species of salmonids was not homogeneous $(P<.005)$, S. namaycush being far more heavily infected than other members of this family. Pippy (MS., 1969) reported that

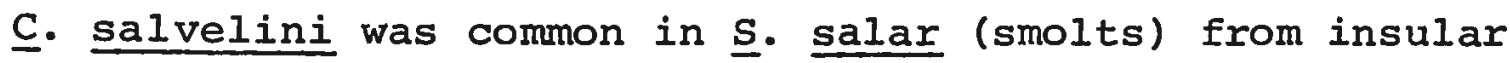
Newfoundland and Great Britain, while Threlfall and Hanek

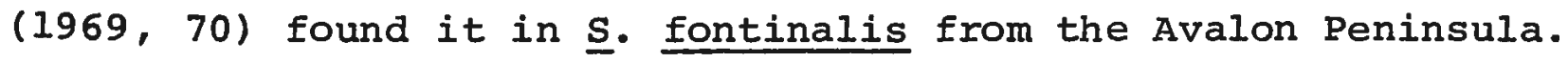
C. salvelini has previously been reported in $\underline{s}$. alpinus, the cherry salmon, Oncorhynchus masu and $\underline{s}$. trutta in the U.S.S.R. (Vide Bykhovsky et al., 1962).

Mature specimens of Contracaecum aduncum were recovered in low numbers (38 infected each) from $\underline{\text { s. salar, }}$ S. namaycush and $\underline{S}$. alpinus. It is of interest to note that Sandeman and Pippy (1967) and Threlfall and Hanek (1970) failed to recover it from the species of salmonids and coregonids they examined from insular Newfoundland. Pippy (MS., 1969) reported that almost all the fish (S. salar) examined from the Miramichi drift net fishing area and the 
Nova Scotia coast (Aspy Bay to scatari) were infected with this parasite (948 and $80 \%$ infected, respectively). Pippy's observation, that $\underline{C}$. aduncum is quickly lost upon entry into the freshwater by the fish host, is supported by the Labrador investigation. Berland (1961b) demonstrated that this parasite is common in marine and migratory fishes in North European waters.

Light infections with Anisakis sp. (larvae) were

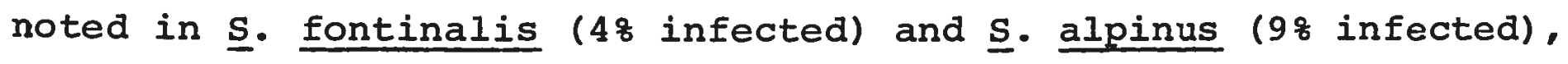

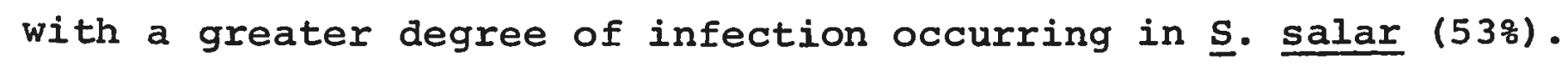
S. namaycush was uninfected. The wide variation in the degree of infection was found to be significant ( $\mathrm{P}<.005)$. Many s. salar from some of the major rivers along the eastern Canadian coast were recovered with this larval nematode (Pippy, MS., 1969). Berland (1961.b) noted that this parasite is common in marine fishes of the North European seas.

\section{Metabronema salvelini documented from a wide}

variety of North American salmonid and coregonid species (vide Hoffman, 1967), was present in all the Labrador species examined, with the exception of $\underline{P}$. cylindraceum (Table 2). A significant difference $(P<.005)$ was noted in the distribution of this helminth in the salmonid species examined (Table 2). The difference in the degree of infection between the salmonid and coregonid species was also significant $(P<.005)$ (34\% of salmonids infected; 28 of coregonids infected). Sandeman and 
Pippy (1967) indicated comparable results to those of Labrador for species of salmonids from insular Newfoundland. The average number of parasites per infected host was generally higher for Labrador salmonid species than for the same species from insular Newfoundland.

Philonema agubernaculum was common in all salmonids with the exception of $\underline{S}$. salar and the coregonids (Table 2). The highest incidence was noted in $\underline{\text { s. alpinus }}$ (20\% infected), lower degrees of incidence being recorded for $\underline{\mathbf{s}}$. fontinalis

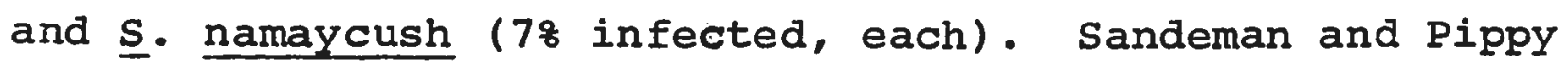
(1967) found $\underline{P}$. agubernaculum in less than 18 of the $\underline{\text { s. fontinalis }}$ they examined, but helminths were "numerous" in individual infected fish. The number of parasites ranged from only 1 - 6 in the present study with a mean of 2.5. Maclulich (1943b) in a study of salmonid species of Algonquin Park, recovered Philonema sp. from S. namaycush, while Meyer (1954) reported this parasite from $\underline{s}$. salar (landlocked) and $\underline{s}$. fontinalis taken in Maine.

\section{Acanthocephalus lateralis was the most widespread}

helminth from Labrador salmonid and coregonid species, being found in all species from all locations. The distribution of this helminth within the species of salmonids was not, however, homogeneous $(P<.005)$, . fontinalis being more heavily parasitized than the other species (Table 2). The 
difference in the degree of infection between the species of salmonids and coregonids was also significant $(P<.005)$ (368 of salmonids infected; $7 \%$ of coregonids infected).

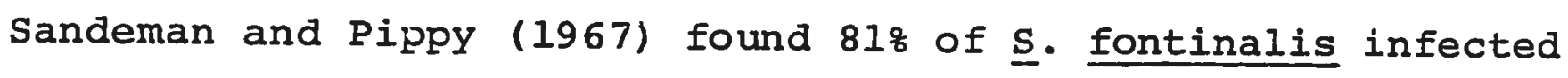
with this helminth, the mean number of parasites per infected fish being greater than in the present study $(40.3: 19.6$, respectively).

The sole parasite recovered from $\underline{\text { c. clupeaformis }}$ from insular Newfoundland, ‥ lateralis (Sandeman and Pippy, 1967; Threlfall and Hanek, 1970), was found only in a few C. Clupeaformis and P. cylindraceum ( 38 and $10 \%$, respectively). The Labrador investigation and a checklist of parasites of the species of coregonids (Hoffman, 1967) indicates a wide range of parasites capable of infecting this fish, a situation that appears to be modified when fish are introduced, as exemplified in $\underline{C}$. clupeaformis from insular Newfoundland.

Salmincola edwardsii was reported from $\underline{\text { s. fontinalis }}$

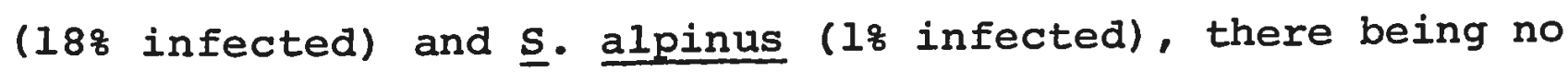
significant difference in the degree of infection. S. exsanguinata (synonymized by Kabata (1969) with $\underline{\mathbf{S}}$ - edwardsii) from s. fontinalis (27\% infected) from insular Newfoundland (Sandeman and Pippy, 1967) was found to be higher than that recorded for Labrador, although the mean number of copepods per infected fish was higher for Labrador $(4.9$ compared to 2.1 for insular New foundland). 
Food items from the stomach contents of the fish examined were identified and may provide valuable information about intermediate hosts of the helminths recovered (Table 18).

The fish examined during the recent study were caught in a relatively restricted area when the total area of Labrador is considered. While giving some idea of the parasite burden of salmonids and coregonids in this area, the study underlines the need for further research in this field. An ecologically - orientated study of the parasites of fish from western Labrador is now underway. 
Table 18. Food items found in fish from coastal Labrador.

Salmo salar (parr, smolt)

Blackflies (Simulium sp.); stonefly adults (Plecoptera); larval chironomids; caddis-fly larvae (Trichoptera); insect remains; vegetation and small fish.

Salvelinus fontinalis

Salvelinus namaycush

Salvelinus alpinus

Coregonus clupeaformis

Prosopium cylindraceum

Gammarus sp. (Amphipoda); Pseudolibrotus litoralis (Amphipoda); caddisfly larvae-stone house (Trichoptera); Cyclorrhapha larvae (Diptera); Coleoptera; insect remains; vegetation; Gasterosteus sp. spider; fish remains; snail shells (Mollusca).

Crustacea; Amphipoda; insect remains; G. aculeatus; Gasterosteidae; Cas tostomidae; Cottidae.

Gammarus sp. (Amphipoda); Pseudolibrotus litoralis (Amphipoda); Odonata nymp; insect larvae;

larval cases (Trichoptera)

insect remains.

snails, bivalves (Mollusca); larval cases-sand (Trichoptera); insect remains; vegetation.

insect larvae; insect remains; larval cases-sand (Trichoptera); vegetation. 
Summary

1. Salmonids and coregonids of Labrador, while economically important from a recreational and commercial viewpoint, have received very little attention, to date, from scientists. As a result of this dearth of information, an ecologically orientated study of the metazoan parasites of these fishes, was initiated in the summer of 1969.

2. Employing conventional parasitological technigues, 323 fish of six species of Salminidae and Coregonidae (Salmo salar, Salvelinus fontinalis, s. namaycush, s.alpinus, Coregonus clupeaformis, Prosopium cylindraceum) from 4 locations along the eastern coast of Labrador (St. Mary's River, Eagle River, Nain, Grand Lake) were examined for metazoan parasites.

3. Raw data was treated statistically $((2 \times 2)$ and $(2 \times c)$ contingency classifications) to determine whether or not the parasite burden was homogeneous with respect to the sex of a particular fish species or the location of the fish species along the Labrador coast. Tests were also performed to determine whether or not all the salmonid species examined had a similar parasite burden, the same tests being applied to the coregonid species. The parasite burdens of salmonid and coregonid species were also compared. 
4. Upon examination of the $323 \mathrm{fish}$, parasites belonging to 24 genera (3 of Monogenea, 8 of Digenea, 5 of Cestoda, 5 of Nematoda, 1 of Acanthocephala, 2 of parasitic Copepoda) were recovered.

5. Salmo salar was found to be infected with 14 genera of metazoan parasites ( 1 of Monogenea, 6 of Digenea, 3 of Cestoda, 3 of Nematoda, 1 of Acanthocephala). Three parasites, Bunodera luciopercae, Metabronema salvelini and Acanthocephalus lateralis were recovered from this fish for the first time.

Significant differences were noted in the incidence of infection and sex of this fish host in the case of B. Iuciopercae $(P<.05)$ and Eubothrium crassum $(P<.005)$ which occurred more frequently in female and male $\underline{s}$. salar, respectively. A. lateralis was noted in a greater percentage of fish from st. Mary's River than from the other areas sampled

The number of parasite species increased with age of the fish, however, there was a decrease noted upon entry of the anadromous fish into the freshwater.

6. Salvelinus fontinalis contained the most diverse parasitofauna of all the species of fish examined ( 21 genera of parasites including 3 of Monogenea, 7 of Digenea, 4 of Cestoda, 5 of Nematoda, 1 of Acanthocephala, 1 of parasitic 
Copepoda). Tetraonchus variabilis, Podocotyle atomon, Diplostomum spathaceum, Derogenes varicus, Brachyphallus crenatus, Anisakis sp. were recovered from this host for the first time. Gyrodactylus sp., closely resembling G. elegans (var. B) Mueller, 1936, and a proteocephalid identified as Proteocephalus tumidocollus were compared with the type specimens and figured.

D. spathaceum was found to occur more frequently in female than male fish $(P<.05)$. The metazoan parasites, Bunodera Iuciopercae, Crepidostomum farionis, Diplostomum spathaceum, Brachyphallus crenatus, Metabronema salvelini and Salmincola edwardsii each exhibited significant differences $(P<.005)$ in their incidence in the various locations sampled.

With an increase in age of $\underline{s}$. fontinalis, there was a corresponding increase in the number of parasite species.

7. Salvelinus namaycush from Nain and Grand Lake were examined, 12 genera of metazoan parasites being recovered (1 of Monogenea, 4 of Digenea, 2 of Cestoda, 4 of Nematoda, 1 of Acanthocephala). Discocotyle sagittata, Bunodera luciopercae, Diplostomum spathaceum, Brachyphallus crenatus, Proteocephalus tumidocollus, Capillaria salvelini,

Contracaecum aduncum and Acanthocephalus lateralis were 
recovered, their presence in this fish constituting a new host record.

Brachyphallus crenatus exhibited a significant difference in its distribution among this species from Nain and Grand Lake $(P<.005)$.

An increased number of parasite species was noted with an increase in age of the fish host. There was also a suggestion that as the fish ages, a point is reached where the parasite burden begins to diminish.

8. Salvelinus alpinus were found to be infected with 16 genera of metazoan parasites ( 6 of Digenea, 3 of Cestoda, 5 of Nematoda, 1 of Acanthocephala, 1 of parasitic Copepoda) from Nain and Grand Lake.

Bunodera luciopercae, Phyllodistomum limnosa, Derogenes varicus, Brachyphallus crenatus, Proteocephalus tumidocollus, Capillaria salvelini, Anisakis sp., Philonema agubernaculum and Acanthocephalus lateralis were recovered, their presence constituting new host records for this fish.

A correlation between the number of parasite species found in a fish and the age of the fish was noted. 
9. Coregonus clupeaformis from Grand Lake were found to be infected with 11 genera fo metazoan parasites ( 1 of Monogenea, 3 of Digenea, 2 of Cestoda, 3 of Nematoda, 1 of Acanthocephala, 1 of parasitic Copepoda).

New host records for this fish include Crepidostomum farionis, Diplostomum spathaceum, Phyllodistomum limnosa, Proteocephalus tumidocollus, Capillaria salvelini, Metabronema salvelini, Philonema agubernaculum and Salmincola extensus.

10. Prosopium cylindraceum from Grand Lake, were parasitised by 11 genera of metazoan parasites ( 2 of Monogenea, 2 of Digenea, 2 of Cestoda, 2 of Nematoda, 1 of Acanthocephala, 2 of parasitic Copepoda).

Tetraonchus variabilis recovered from this fish species was compared with the type specimen of Mizelle and Webb, 1953 and figured. Ergasilus luciopercarum recovered from $\underline{\text { P. }}$ cylindraceum for the first time was also figured.

11. The incidence of Bunodera luciopercae in salmonids and coregonids was compared, a distinct predilection being noted for the former $(P<.005)$.

12. Crepidostomum farionis exhibited a significant difference $(P<.005)$ in the number of salmonid species 
infected, while the high incidence of the helminth in ' salmonids and low incidence in coregonids was also significantly different $(P<.005)$.

13. Metacercariae of Diplostomum spathaceum occurred more frequently in coregonid species than in salmonids, this difference being significant $(P<.005)$.

14. Brachyphallus crenatus was found to infect salvelinus

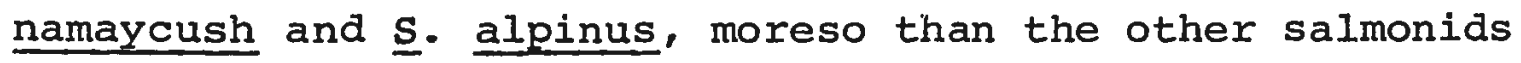
examined. This distribution was not homogeneous $(P<.005)$.

15. The distribution of Eubothrium crassum in the salmonids infected was not homogeneous $(P<.005)$, this parasite occurring most frequently in s. salar.

16. Capillaria salvelini exhibited an unequal distribution within the species of salmonids $(P<.005)$, . namaycush being far more heavily infected than other members of this family.

17. The wide variation in the degree of infection of Iabrador salmonids with Anisakis sp. larvae was found to be significant $(P<.005)$. Fifty-three percent of $\underline{\mathrm{s}}$. salar examined were infected with this nematode.

18. Significant differences $(P<.005)$ were noted in the distribution of Metabronema salvelini among salmonids and 
in the degree of infection between the salmonid and coregonid species ( 348 of salmonids infected: 28 of coregonids infected).

19. The distribution of Acanthocephalus lateralis within the species of salmonids was not homogeneous $(P<.005)$, S. fontinalis being more heavily parasitized than the other species. The difference in the degree of infection between the salmonids and coregonids was also significant $(P<.005)$ (36\% of salmonids infected : $7 \%$ of coregonids infected). A. lateralis was found in very low percentages (< $10 \%)$ of coregonids in contrast to the high percentages recorded for C. clupeaformis by Sandeman and Pippy, 1967 and Threlfall and Hanek, 1970.

20. Food items from the stomach contents of the fish examined were identified and tabulated. 
References

American Fisheries Society, Committee on Names of Fishes. 1960. A list of common and scientific names of fishes from the United States and Canada. (2nd. ed.) Am. Fish. Soc. Publ. No. 2, Waverly Press Baltimore, $102 \mathrm{pp}$.

Andrews, C. W. and E. Lear. 1956. The biology of Arctic char (Salvelinus alpinus I.) in northern Labrador. J. Fish. Res. Bd. Canada, 13(6): 843-860.

Backus, R. H. 1957. The fishes of Labrador. Bull. Amer. Mus. Nat. Hist. $113(4): 273-338$.

Baer, J. G. 1952. Ecology of animal parasites. The University of Illinois Press, Urbana, ix + 224pp.

Bangham, R. V. 1955. Studies on fish parasites of lake Huron and Manitoulin Island. Amer. Midl. Nat., $53(1): 184-194$

Bangham, R. V. and J. R. Adains. 1954. A survey of the parasites of freshwater fishes from the mainland of British Columbia. J. Fish. Res. Bd. Canada, $11(6): 673-708$

Bere, R. 1931. Copepods parasitic on fish of the Trout Lake region, with descriptions of two new species. Tr. Wisconsin Acad., Arts and Lett., $26:$ 427-436. 
Berland, B. 196la. Use of glacial acetic acid for killing parasitic nematodes for collection purposes. Nature 191(4795): 1320-1321.

Berland, B. 1961b. Nematodes form some Norwegian marine fishes. Sarsia (2): 1-50.

Brinkman, A. (Jr.) 1952. Fish trematodes from Norwegian waters. Univ. Bergen Aarbok, Nature Rek., (1): 134. Bullock, W. L. 1969. Morphological features as tools and as pitfalls in acanthocephalan systematics. In: Problems in systematics of parasites. G. D. Schmidt (ed.) University Park Press, Baltimore, Maryland and Manchester, England.

Burt, M. D. B. and I. M. Sandeman. 1969. Biology of Bothrimonus (Diplocotyle) (Pseudophyllidea: Cestoda) Part I. History, description, synonymy, and systematics. J. Fish. Res. Bd. Canada 26: 975-996. *Bykhovsky, B. E. 1936. Parasitological investigations in lakes Barabinskye. Mag. Parasit., Moscow, VI. Bykhovsky, B. E. et al. 1962. Key to parasites of freshwater fishes of the U.S.S.R. Publ. House Acad. Sci. U.S.S.R., Moscow-Leningrad. (Transl. from Russian by Israel Program for Sci. Transl., Jerusalem, 1964). 
*Bykhovskaya-Pavlovskaya, I. E. 1940. The influence of age on parasite fauna of perch. Mag. Parasit., Moscow, VIII.

Cable, L. E. 1956. Validity of age determination from scales, and growth of marked Lake Michigan lake trout. U.S. Fish Wildlife Service. Fishery Bulletin 57: 1-59.

Chen, M. Y. MS 1967. Aspects of the biology of the lake whitefish, Coregonus clupeaformis (Mitchill) in Hogan's Pond, Avalon Peninsula, Newfoundland. M.Sc. Thesis, Memorial University of Newfoundland, st. John's, Newfoundland.

Choquette, I. P. E. 1948. Parasites of freshwater fish. IV. Internal helminths parasitic in speckled trout (Salvelinus fontinalis (Mitchill)) in rivers and lakes of the Laurentide Park, Quebec, Canada. Can. J. Res. D, 26: 204-211.

Cooper, A. R. 1915. Trematodes from marine and freshwater filshes, including one species of ectoparasitic turbellarian. Trans. Roy. Soc. Can., Ser. 3, 9 (sec. 4): 181-205.

Davis, C. C. 1969. Ergasilus luciopercarum males in an unusual collection from Newfoundland. Can. J. Zool. $47:$ 1249-1252. 
Davis, H. S. 1953. Culture and diseases of game fishes. Univ. Calif. Press., Berkeley. $332 \mathrm{pp}$.

Dawes, B. 1947. The Trematoda of British fishes. Ray Society, London, 364 pp.

Dawes, B. 1968. The Trematoda, with special reference to British and other European Forms. Cambridge Univ. Press, London. $x v i+644 \mathrm{pp}$.

Dechtiar, A. 1966. A new species of Phyllodistomum

(Trematoda: Gorgoderidae) from Coregonus clupeaformis (Mitchill) from Lake of the Woods (Ontario). Can. J. Zool. $44(1): 135-140$.

Dogiel, V. A. 1933. Problems in the study of the parasite fauna of fish (Methods and problems of ichthyoparasitological research). Trudy Leningradskogo Obsh., 62(3) : 247-268. Fish. Res. Bd. Canada Transl. Ser. No. 781 : 44 pp. 1966.

*Dogiel, V. A. 1935. The sequence of tasks of ecological parasitology. Trud. petergot. biol. Inst. $15: 31-48$.

Dogiel, V. A. 1958. Ecology of the parasites of freshwater fishes.

In: Parasitology of Fishes. Ed. Dogiel, V. A.,

G K. Petrushevski and Y. I. Polyanski.

Oliver and Boyd, Edinburgh and London.

Transl. by Z. Kabata, 1961. 
Dogiel, V. A. 1962. General Parasitology. Oliver and Boyd Ltd., Edinburgh and London. (English transl. Z. Kabata, 1964).

Dogiel, V. A. and G. S. Petrushevski. 1935. An ecological study of the parasites of the salmon. Publ. Ecol. and Biocenol. Leningrad, 2: 137-169. (In Russian).

Dollfus, R. Ph. 1942. Etudes critiques sur les Tetrarhynques du Museum de Paris. Arch. Mus. Hist. Nat. (Paris) $19: 1-466$.

Dollfus, R. Ph. 1953. Apercu general sur l'histoire naturelle des parasites animaux de la morue atlantoarctique Gadus callarias (morhua L.). Encycl. Biol. 43.

Dubois, A. and R. Lageux. 1968. Etude comparee de l'age scalaire et de l'age otolothique de la toulade (Salvelinus namaycush), lac Mistassini, Quebec. Natur. Can. 95(4): 907-928.

Freeman, R. S. 1964. On the biology of Proteocephalus parallacticus MacLulich (Cestoda) in Algonquin Park, Canada. Can. J..Zool. 42: 387-408. Freze, V. I. 1965. Essentials of Cestodology. Volume V. Proteocephalata in fish, amphibians, and reptiles. Academy of Sciences of the USSR. Helminthological Laboratory. 597 pp. 
Frost, N. 1940. A preliminary study of Newfoundland trout. Newfoundland Research Bull. 9: 1-30.

Grenfell, Wilfred T. et al. 1913. Labrador, the country and the people. The MacMillan Company, New York.

Hanek, G. and W. Threlfall. 1970a. Parasites of the Threespine Stickleback (Gasterosteus aculeatus) in Newfoundland and Iabrador. J. Fish. Res. Bd. Canada 27: 901-907.

Hanek, G. and W. Threlfall. 1970b. Metazoan parasites of the American eel (Anguilla rostrata (Lesueur)) in Newfoundland and Labrador. Can. J. Zool. $48(3): 597-600$

Hanek, G. and W. Threlfall. 1970c. Parasites of the ninespine stickleback Pungitius pungitius (I.) in Newfoundland and Labrador. Can. J. Zool. $48(3): 600-602$.

Hanek, G. and W. Threlfall. 1970d. Monogenetic trematodes from Newfoundland Canada. 2. New species of the genus Gyrodactylus Nordmann, 1832 from Labrador cottids. Can. J. Zool. 48(5): 915-918.

Hart, J. I. 1931. The food of the whitefish, Coregonus clupeaformis (Mitchill), in Ontario waters, with a note on the parasites. Contrib. Canadian Biol. Fish., N.S. $6(21): 447-454$. 
Heitz, F. A. MS 1917. Salmo salar, its parasitic fauna and its nutrition in the sea and in freshwaters.

A parasitological-biological study.

Ph.D. Thesis, Univ. Basel, Stuttgart, 139 pp.

Fish. Res. Bd. Canada Transl. Ser. No. 717, 1966.

Heller, A. F. 1949. Parasites of cod and other marine

fish from the Baie de Chaleur Region.

Can. J. Res. D., $27(5): 243-264$.

Hoffman, G. L. 1960. Synopsis of Strigeoidea (Trematoda)

of fishes and their life cycles.

U. S. Fish and Wildlife Service, Fishery Bulletin

175, Vol. $60: 439-469$.

Hoffman, G. L. 1967. Parasites of North American Freshwater

Fishes. Univ. of California Press. Berkely and

Los Angeles 1967. 486 pp.

I.C.N.A.F. 1970. International Commission for the

Northwest Atlantic Fisheries, Annual Proceedings.

Vol. 20 for 1969-70. Issued from Headquarters of

the Commission, Dartmouth, N.S.

Jones, J. W. 1959. The Salmon. Collins, St. James Place,

London.

Kabata, z. 1969. Revision of the genus Salmincola Wilson,

1915 (Copepoda: Lernaeopodidae).

J. Fish. Res. Bd. Canada 26: 2987-3041. 
*Kazadaev, V. I. 1954. Parasitic invasions of tench and their influence on the fish. Report, Mosrybvtuz. Kennedy, C. R. 1969. Occurrence of Eubothrium crassum (Cestoda: Pseudophyllidea) in salmon salmo salar and trout $\underline{s}$. trutta of the river Exe. Journal of Zoology-Proc. Zool. Soc. of London Vol. $157(1): 1-9$.

Lagler, K. L. 1947. Lepidological studies 1. Scale characters of the families of Great Lakes fishes. Tr. Am. Micr. Soc. $66(2): 149-171$.

Lagler, K. I. 1956. Freshwater fishery biology. Wm. C. Brown Company, Dubuque Iowa. 421 pp. *Layman, E. M. 1955. The age dynamics of infestation of fish with parasites. Tr. Mosrybvtuza, VII.

Leim, A. H. and W. B. Scott. 1966. Fishes of the Atlantic coast of Canada. Bull. Fish. Res. Bd. Canada, No. 155 .

Linton, E. 1940. Trematodes from fishes mainly from the Woods Hole region, Massachusetts. Proc. U.S. Nat. Mus. 88: $1-172$.

Mackay, H. H. 1963. Fishes of Ontario. The Bryant Press Limited, Toronto. 300 pp. 
Maclulich, D. A. 1943a. Proteocephalus parallacticus,

a new species of tapeworm from lake trout, Cristivomer namaycush. Can. J. Res. Sect. D., $21: 145-149$.

Maclulich, D. A. 1943b. Parasites of trout in Algonquin Provincial Park, Ontario. Can. J. Res. Sect. D., $21: 405-412$.

Malmberg, G. 1956. Om forekomsten av Gyrodactylus pa svenska fiskar. Skr. Utgivna Sodra Sveriges Fiskeriforening Arsskr. 1956: 19-76.

*Mamaev, Yu. A., A. M. Parukhin, O. M. Baeva and P. G. Oshmarin. 1959. Helminthofauna of Far East salmonids in connection with problems of local populations and migratory paths of these fish. (In Russian). Maritime (Primorskoe) Book Publishers. pp. 1-73, vladivostok.

Margolis, L. 1963. Parasites as indicators of the geographical origin of sockeye salmon oncorhynchus nerka (Walbaum), occurring in the north Pacific Ocean and adjacent seas. Int'l North Pacific Fisheries Commission, Bull. No. 11: 101-156. 
Margolis, L. 1965. Parasites as"an auxiliary source of information about the biology of Pacific salmons (genus Oncorhynchus) . J. Fish. Res. Bd. Canada, 22 : $1387-1395$.

Margolis, I. 1970. Nematode diseases of marine fishes.

In: A symposium on diseases of fishes and shellfishes. Ed. S. F. Snieszko. Am. Fish. Soc. Special Publication No. 5: 190-208.

Markevich, A. P. 1951. Parasitic fauna of freshwater fish of the Ukrainian S.S.R. Academy of Sciences of the Ukrainian S. S. R., Zoological Institute. Kiev. (English Transl. Israel Program for Scientific Transl.).

McPhail, J. D. and C. C. Lindsey. 1970. Freshwater fishes of northwestern Canada and Alaska. Bull. Fish. Res. Bd. Canada, No. 173.

Meyer, M. C. 1954. The larger animal parasites of the freshwater fishes of Maine. Maine Dept. Inland Fish and Game. Fish. Res. and Manag. Div. Bull. No. 1, $92 \mathrm{pp}$.

Miller, M. J. 1941. A critical study of stafford's report on "Trematodes of Canadian Fishes" based on his trematode collection. Can. J. Res. 19: 28-52. 
Mizelle, J. D. and F. O, Webb. 1953. Studies on monogenetic trematodes. XV. Dactylogyridae from Alaska, Wisconsin and Wyoming. Amer. Midl. Nat. 50(1): 206-217.

Mraz, D. 1964. Age and growth of the round whitefish in Lake Michigan. Trans. Am. Fish. Soc. 93: 46-52. Mueller, J. F. 1936. Studies on North American Gyrodactyloidea. Tr. Am. Micr. Soc. 55(1): 55-72.

Munroe, E. G. 1949. Notes on the fish of the interior of the Labrador Peninsula. Arctic, $2(3): 165-173$. Noble,E.R. 1960. Fishes and their parasite-mix as objects for ecological studies. Ecology, 41: 593-596. Nordeng, H. 1961. On the biology of char (Salmo alpinus L.) in Salangen, North Norwayl. Age and spawning frequency determined from scales and otoliths. Nytt. Magasin for Zoologi. 10: 67-123.

Paling, J. E. 1965. The population dynamics of the monogenean gill parasite Discocotyle sagittata Leuckhart on Windermere trout, Salmo trutta $\mathrm{L}$. Parasitology 55(4): 667-694.

*Pavlovski, E. N. 1934. Organism as environment. Priroda 1. Peet, R. F. 1971. A report on the counting trap and reconnaissance surveys conducted in central coastal Labrador. Resource Development Branch, Dept. of Fisheries and Forestry, St. John's, Newfoundland. 
Pippy, J. H. C. MS 1965. Studies on the parasites of fresh-water fishes (Salmonidae and Coregonidae) of insular Newfoundland.

M.Sc. Thesis, Memorial University of Newfoundland, st. John's, Newfoundland, $170 \mathrm{pp}$.

Pippy, J. H. C. MS 1969. Preliminary report on parasites as biological tags in Atlantic salmon (Salmo salar). 1. Investigations 1966-1968.

Fish. Res. Bd. Canada, Tech. Rept. No. 134: 1-44.

Power, G. 1969. The salmon of Ungava Bay. Arctic Institute of North America. Technical paper No. 22.

Price, E. W. 1937. A new monogenetic trematode from Alaskan salmonoid fishes. Proc. Helminth. Soc. Washington, $4(1): 27-29$.

Price, E. W. 1943. North American monogenetic trematodes VII. The Family Discocotylidae (Diclidophoroidea). Proc. Helminth. Soc. Wash. $10(1): 10-15$.

*Rakova, V. M. 1954. Infestations of Leuciscus idus and their influence on that fish. Report, Mosk, tekhn. in-t ryb. prom. khoz.

Richardson, L. R. 1936. Observations on the parasites of the speckled trout in Lake Edward, Quebec. Tr. Am. Fish. Soc. 66: 343-356.

Riser, N. W. MS 1949. Studies on the Tetraphyllicea. Ph.D. Thesis. Stanford University. 
Roberts, L. S. 1970. Ergasilus (Copepoda: Cyclopoida): Revision and key to species in North America. Tr. Am. Micr. Soc. $89(1)$ : 134-161.

Rubin, R. 1951. A rapiā method for making permanent mounts of nematodes. Stain Technology $26(4)$ : 257-260.

Sandeman, I. M. and J. H. C. Pippy. 1967. Parasites of freshwater fishes (Salmonidae and coregonidae) of insular Newfoundland. J. Fish. Res. Bd. Canada $24(9)$ : 1911-1943.

Schell, S. C. 1962. Parasitology Laboratory Manual. John Wiley and Sons Inc. New York / London.

Scott, W. B. and E. J. Crossman. 1964. Fishes occurring in the fresh waters of insular Newfoundland. Dept. of Fisheries. Queen's Printer, Ottawa, 1-124 pp.

*Shaffer, E. 1916. Discocotyle salmonis nov. spec., ein neuer Trematode an den Kiemen der Regenbogenforelle (Ślmo irideus). Zool. Anz. 46: 257-271.

*Shaw, J. N. 1947. Some parasites of Oregon wild life. Oregon Agric. Exper. Sta., Sta. Tech. Bull. $11: 3-15$.

Simpson, G. C., A. Roe and R. C. Lewontin. 1960. Quantitative zoology. Harcourt, Brace and World Inc. New York, Chicago, San Francisco, Atlanta (Revised) 440 pp. 
Skrjabin, K. I. 1960. Essentials of Trematodology. Vol. XVII. Trematodes of Animals and Man. Academy of Sciences of the USSR. Helminthological Laboratory, Moscow. (English Transl. Israel Program for Scientific Transl. 1964).

Smith, F. R. MS 1970. Helminth parasites of Newfoundland mammals. M.Sc. Thesis. Memorial University of Newfoundland, St. John's, Newfoundland.

Stafford, J. 1904. Trematodes from Canadian fishes. Zool. Anz. 27: 481-495. *Theodorides, J. 1954. Părasitisme et écologie. Biol. Med., Paris 43(4): 1-24.

Threlfall, W. 1968a. The helminth parasites of three species of gulls in Newfoundland. Can. J. Zool. $46(5): 827-830$.

Threlfall, W. 1968b. Studies on the helminth parasites of the American herring gull (Larus argentatus Pont.) in Newfoundland. Can. J. Zool. 46(6): 1119-1126. Threlfall, W. 1969. Further records of helminths from Newfoundland mammals. Can. J. Zool. 47(2): 197-201. Threlfall, W. and G. Hanek. 1969. Capillaria salvelini Polyanski, 1952 from Salvelinus fontinalis (Mitchill). Can. J. Zool. 47(5): 1088-1090. 
Threlfall, W. and G. Hanek. 1970a. Metazoan parasites, excluding Monogenea, from longnose and white suckers. J. Fish. Res. Bd. Canada, 27: 1317-1319. Threlfall, W. and G. Hanek. 1970b. Helminths from Northern Pike (Esox lucius L.) in Labrador. Jour. Parasit. $56(4): 662$.

Threlfall, W. and G. Hanek. 1970 . Metazoan parasites of salmonids and coregonids from the Avalon Peninsula, Newfoundland. J. Fish. Res. Bd. Canada 27: $1894-1897$.

Vik, R. 1963. Studies of the helminth fauna of Norway IV. Occurrence and distribution of Eubothrium crassum (Bloch, 1779) and E. salvelini (Schrenk, 1790) (Cestoda) in Norway, with notes on their life cycles. Nytt. Magasin for Zoologi., 11: 47-73.

Wagner, E. D. 1953. A new species of Proteocephalus Weinland, 1858 (Cestoda), with notes on its life history. Tr. Am. Micr. Soc. $72(4): 364-369$. Wagner, E. D. 1954. The life history of Proteocephalus tumidocollus Wagner, 1953 (Cestoda), in rainbow trout. J. Parasitol., $40(5): 489-498$.

Wardle and McLeod. 1952. The Zoology of Tapeworms. University of Minnesota Press. $780 \mathrm{pp}$.

Yamaguti, s. 1958. Systema helminthum. Vol. I, Parts I and II. Digenetic trematodes of vertebrates. Interscience, New York, 1575 pp. 
Yamaguti, S. 195.9. Systema helminthum. Vol. II. The cestodes of vertebrates. Interscience, New York, $860 \mathrm{pp}$.

Yamaguti, S. 1961. Systema helminthum. Vol. III. Parts I and II. The nematodes of vertebrates. Interscience, New York, 1261 pp.

Yamaguti, S. 1963. Systema heIminthum. Vol. IV. Monogenea and Aspidocotylea. Interscience, New York, $699 \mathrm{pp}$.

Yin, W. and N. G. Sproston. 1948. Studies on the monogenetic trematodes of China. Sinensia, $19: 58-85$

* not seen 
. 
. 
